AÜiFD 47 (2006), sayı l, s. 11-53

\title{
Geleneksel Kur'an Tasavvurunun Tefsir İlminin Oluşumuna ve Gelişimine Etkisi
}

\author{
ALİ RIZA GÜL \\ Doç. Dr., YÜZÜNCÜ YIL Ü. İLAHIYAT FAKÜLTESI \\ e-posta: alirizagul@hotmail.com; aliriza64@mynet.com
}

\begin{abstract}
The Influence of Classical Koran Thought on the Formation and Development of Commentary Science. Muslims absolutely believe that the Koran is the word of the God. According to common opinion, the Koran had been revealed to Mohammad in current arrangement of surahs and verses. This point of view caused the text and external meaning of the surahs and verses to be given preference and its verses are interpreted according to current arrangement. Yet its arrangement of this way neither obstructed the relations of the verses in doing commentaries, nor prevented the verses those are about a common topic from being interpreted totally. In the same way, commentators didn't get stuck with the literal meanings of the verses, but they also took into consideration the historical background, goals, textual context (siyâq) etc. of the verses. They also utilized the hadiths of the Prophet Mohammad, the Arabic language and literature, and humanities and social sciences like ethics, history, jurisprudence, economy, psychology and cosmology.
\end{abstract}

key words

Revelation, classical Koran thought, style of Koran, arrangement of the surahs, arrangement of the verses.

\section{Giriş}

Her metnin kendine ait birtakım hususiyetlerinin bulunduğu, bunların o metne bakış açısını ve anlaşılmasını yoğun bir şekilde etkilediği inkâr edilemez bir gerçektir. Vahiy sürecinin en son kutsal kitabı olarak Kur'ân'ın da kendine özgü bazı özellikleri vardır ve bunlara verilen anlam ona bakış açısını önemli oranda belirlemektedir. Bu bakımdan onun anlam derinliğini kavramaya yönelik bir metot geliştirmeden önce, onun bu özelliklerini tespit etmenin zorunluluğu ortadadır. Zira Kur'ân'ın nasıl bir kitap olduğunun tespiti, buna uygun anlama ve açlklama metodunun ipuçlarını da verecek- 
tir. Kanaatimizce, gerek klasik tefsir usulünün, gerekse çağdaş metot arayışlarının başlangıç noktası büyük ölçüde burasıdır. Çünkü bu kutsal metnin özniteliklerinin, şekil, tertip ve üslup özelliklerinin neler olduğunun ortaya konması, hem "Kur'ân nedir? Nasıl bir kitaptır? Amaç ve hedefleri nelerdir?" türünden sorulara kapsamlı bir cevap teşkil edecek, hem de bu kutsal metnin nasıl anlaşılması ve açıllanması gerektiğinin temel kriterlerini oluşturacaktır. Bu araştırmanın amacı, sahabiler döneminden itibaren Müslümanlar arasında genel kabul gören Kur'ân anlayışını ve bunun gerek Kur'ân tefsirinin şekillenmesine, gerekse klasik tefsir usulünün oluşumuna etkilerini ortaya koymak suretiyle, ilâhî kitabın daha iyi anlaşılması amacını güttüğünden emin olduğumuz çağdaş metot arayışlarına -en azından nereden başlanması gerektiği noktasında- mütevazı bir katkı sağlamaktır. Kanaatimizce, bu önemli bir husustur; çünkü Kur'ân'ın ne olduğuna dair bir bakış açısı geliştirmeden, tefsir ve usulü ile ilgili olarak ileri sürülen hemen her görüşün, başlangıç noktasından, tabiri caizse, diğer bütün unsurların üzerine bina edileceği temelden ve giriş kapısından yoksun kalacağını söylemek, izahtan varestedir. Bizim gördüğümüz kadarıyla, klasik usulcüler ve müfessirler, usul anlayışlarını, Kur'ân'la ilgili görüşleri doğrultusunda belirlemişlerdir. Onların bu görüşlerini, Kur'ân'ın öznitelikleri, şekilsel özellikleri başlıkları altında ele almak mümkündür.

\section{Kur'ân'ın Öznitelikleri}

Biz, "Kur'ân'ın öznitelikleri” tabiriyle, onun metnini diğer metinlerden farklılaştıran ana özellikleri, yani ismi, kaynağı, amaçları, sıfatları, konuları ve üslubu gibi bir anlamda kimliğini oluşturan nitelikleri kastediyoruz. Bizzat Kur'ân kendi öznitelikleri hakkında bazı bilgiler vermektedir. Gerek müfessirler ilgili ayetleri tefsir ederlerken, gerekse usul alimleri ilgili konuları incelerlerken, Kur'ân'ın özniteliklerini detaylandırmışlardır. Biz burada bu özellikleri tek tek sıralayarak açıklayacak değiliz. Burada yapacağımız, genel bir bakış açısıyla onun ana özelliklerine işaret etmektir.

\section{a. İsimleri ve Sıfatları}

Usulcüler ilâhî kitabı isimlendirirlerken, o kitabın kendisine atfettiği isimleri esas almışlardır. Ancak ilâhî kitabın kendisiyle ilgili tanıtımları, nitelendirmeleri ve övgüleri de isim olarak değerlendirdiklerinden, çeşitli ayetlerden hareketle çok sayıda isim türetmişlerdir. ${ }^{1}$ Bununla birlikte onlar, ilâhî

1 Bu isimler ve anlamları hakkında geniş bilgi için bkz. Bedreddîn Muhammed b. Abdullah ezZerkeşî, el-Burhân fî ulûmi'l-Kur'ân, thk. Muhammed Ebu'l-Fadl İbrahim, Beyrut: Dâru'l-ceyl, 
kitabın ilk ve en önemli isminin Kur'ân olduğu hususunda görüş birliği içerisindedirler. Zira bizzat Kur'ân, altmışın üzerinde ayette kendisini bu adla adlandırmaktadır. ${ }^{2}$ Mekke döneminin hemen başında inen ${ }^{3}$ Müzzemmil Suresi'nde Hz. Muhammed'e 'Kur'ân'ı tane tane oku.' denilmesi (4'üncü ayet), bu ismin İslâm'ın çok erken zamanlarında bile ilk Müslümanlar tarafından kullanıldığını açık bir biçimde göstermektedir. Yine buradan, ilâhî kelamın tamamına olduğu gibi, bir kısmına, sözgelimi, bir ayetine de Kur'ân denilebileceği anlaşılmaktadır ki, bunu müfessirlerle usulcüler de kabul etmektedir. ${ }^{4}$ Her ne kadar İslâm alimleri bu ismin kökeni ve anlamı üzerinde fikir ayrılığına düşmüşlerse de, yaygın olan kanaat, Kur'ân kelimesinin "okuma" anlamındaki ka-ra-e kökünden türetilerek, "ezberden veya kitaptan okunan" manasına gelen ve Hz. Peygamber'e vahyedilen ilâhî kelamı ifade edecek şekilde kavramlaştırılan bir masdar-isim olmasıdır. ${ }^{5}$ Özellikle Yahudilerin, Hicaz Araplarını "ümmî" (okuma-yazma bilmeyen, kitapsız, cahil) olarak nitelendirmeleri karşısında bu isim, hem Araplar için önemli bir kültürel dönüştürücü olarak görülebilir, hem de İslâm kültürünün en geniş anlamıyla "okuma" temeline dayandırılması gerektiğine bir vurgu olarak değerlendirilebilir. Çeşitli ayetlerde bu isim, hikmetli, ${ }^{6}$ yüce / büyük, ${ }^{7}$ doğru yola

1408/1988, I, 273 vd.; Celâleddîn Abdurrahman b. Ebî Bekir es-Suyûtî, el-İtkân fí ulûmi’l-Kur'ân, Beyrut: Dâru'l-fikr, 1416/1996, I, 141 vd.; İsmail Cerrahoğlu, Tefsir Usulü, 4. bask1, Ankara: Semih Ofset, 1983, s. 34-36.

Kur'ân'ın isimlerini havi olduğu düşünülen ayetlerin tamamının listesi için bkz. Muhammed Bessâm Rüşdî ez-Zeyn, el-Mu'cemü'l-müfehres li meâni'l-Kur'âni'l-azîm, Dimaşk: Dâru'l-fikr Beyrut: Dâru'l-fikri'l-muâsır, 1416/1995, II, 920-29.

2 Örnek olarak bkz. Bakara (29, 185; Nisâ (4), 82; A'râf (7), 204; Yûsuf (12), 2-3; İsrâ (17), 9 , 106; Zuhruf (43), 3; Ahkâf (46), 29; Cin (72), 1. Diğer örnekler için bkz. Muhammed Fuâd Abdulbâkî, el-Mu'cemü'l-müfehres li elfâzı'l-Kur'âni'l-kerîm, İstanbul: el-Mektebetü'l-İslâmiyye, 1982, s. 539-40.

3 Muhammed Esed, Kur'ân Mesajı Meal-Tefsir, çev. C. Koytak-A. Ertürk, İstanbul: İşaret Yay., 1999/ 1420, s. 1199; Cerrahoğlu, Tefsir Usulü, 86.

4 ez-Zerkeşî,el-Burhân, I, 264; Muhammed Hamdi Yazır, Hak Dini Kur'ân Dili- Türkçe Tefsir, İstanbul: Eser Kitabevi, 1960, I, 162; Muhammed Abdulazîm ez-Zerkânî, Menâhilü'l-irfân fì ulûmi'lKur'ân, Beyrut: Dâru ihyâi't-türâsi'l-Arabî, 1416/1995, I, 22.

5 Bu konuyla ilgili tartışmalar için bkz. ez-Zerkeşî, el-Burhân, I, 277-79; Fahreddin Muhammed b. Ömer b. el-Hüseyin el-Hasan b. Ali et-Teymî er-Râzî, et-Tefsîru'l-kebîr (Mefâtîhu'l-gayb), Beyrut: Dâru'l-kütüb el-ilmiyye, 1411/1990, II, 13-14; Muhyiddin Ebû Abdillah Muhammed b. Süleymân el-Kâfiyeci el-Hanefî, Kitâbû't-taysîr fî kavâidi 'ilmi't-tafsîr, Metni tercüme ve notlarla birlikte neşre hazırlayan: İsmail Cerrahoğlu, 2. baskı, Ankara: AÜIF Yayınları, 1989, s. 15 (Türkçe'si için bkz. s. 56); es-Suyûtî, el-İtkân, I, 144; Cerrahoğlu, Tefsir Usulü, 31-32; Ali Turgut, Tefsir Usulü ve Kaynaklart, İstanbul: M.Ü.İFAV Yay., 1991, s. 75-76.

6 Yûnus (10), 1; Yâsîn (36), 2.

7 Hicr (15), 87. 
yönlendiren, olağanüstü, ${ }^{8}$ uyarıc1/öğüt verici, ${ }^{9}$ şerefli / özlü (el-mecîd), ${ }^{10}$ değerli (kerîm), ${ }^{11}$ eğrisizi ${ }^{12}$ ve apaçı ${ }^{13}$ vasıflarıyla nitelendirilmekte, Kur'ân ayetleri arasında ayırım yapılmaması, bunlara kısmen değil, tamamen iman edilmesi istenmektedir. ${ }^{14}$

Kur'ân'ın yaygın olan diğer ismi Kitap'tır. "Yazmak" anlamında masdar iken, örfte "yazılmış" anlamında bir isme dönüşen bu kelime, ${ }^{15}$ ayetlerde hem diğer kutsal kitaplar (Tevrat, Zebur ve İncil), ${ }^{16}$ hem de Kur'ân için isim olarak kullanılmaktadır. ${ }^{17}$ Böylece vahiy sürecinin bir ürünü olduğuna işaret edilen bu kitap, kendinden önceki kitapları doğrulayan, ${ }^{18}$ bununla birlikte onlar içerisinde nelerin doğru olduğunu belirleyen (müheymin), ${ }^{19}$ hakka ve dosdoğru yola yönlendiren, ${ }^{20}$ hidayet rehberi, ${ }^{21}$ mü'minler için müjde, ${ }^{22}$ rahmet, ${ }^{23}$ mübarek / mukaddes, ${ }^{24}$ nûr, ${ }^{25}$ hikmetli, ${ }^{26}$ her şeyi açıklayıc1 ${ }^{27}$ gerçek (hak), ${ }^{28}$ apaçık, ${ }^{29}$ yüce, ${ }^{30}$ aziz, ${ }^{31}$ içerisinde hiçbir şüphe bulunmayan, ${ }^{32}$ ayetleri sağlam / muhkem, ${ }^{33}$ ayetleri birbirine benzer ve uyumlu ${ }^{34}$

8 Cin (72), 1-2

9 Sâd (38), 1.

10 Kâf (50), 1; Burûc (85), 21.

11 Vâkı (56), 77.

12 Zümer (39), 28.

13 Hicr (15), 1; Yâsîn (36), 69.

14 Hicr (15), 90-91.

15 Yazır, Hak Dini Kur'ân Dili, I, 162.

16 Bakara (2), 44, 144, 146; Âl-i İmrân (3), 19, 100; En'âm (6), 20. Diğer örnekler için bkz. Muhammed Fuâd Abdulbâkî, el-Mu'cemü'l-müfehres, 592-95.

17 Bakara (2), 2; Âl-i İmrân (3), 3, 7; Mâide (5), 48.

Çeşitli ayetlerde geçen "kitap" kelimelerinden bazıları Kur'ân-ı Kerim'i, bazıları da Tevrat, İncil gibi diğer ilâhî kitapları ve sahifeleri ifade etmek üzere kullanılmaktadır. Aynı zamanda bu kelime genel anlamda kitap, amel defteri, yazg1 / kader, levh-i mahfûz gibi anlamlara da gelmektedir. İlgili ayetlerin geniş bir tasnifi için bkz. ez-Zeyn, el-Mu'cemü'l-müfehres, II, 978-86.

18 Âl-i İmrân (3), 3; Bakara (2), 89; Mâide (5), 48; En'âm (6), 92; Fâtır (35), 31; Ahkâf (46), 30. 19 Mâide (5), 48. Krş. Mâide (5), 15.

20 Ahkâf (46), 30.

21 Bakara (2), 2; Nahl (16), 64; Neml (27), 2; Lokmân (31), 3.

$22 \mathrm{Neml}(27), 2$.

23 Nahl (16), 64; Lokmân (31), 3.

24 En'âm (6), 92, 155; Sâd (38), 29.

25 Mâide (5),15.

26 Yûnus (10), 1; Lokmân (31), 2; Zuhruf (43), 4.

27 Nahl (16), 89.

28 Secde (32), 3; Fâtır (35), 31.

29 Mâide (5), 15; Yûsuf (12), 1; Şuarâ (26), 2; Neml (27), 1; Kasas (28), 2; Zuhruf (43), 2; Duhân (44), 2.

30 Zuhruf (43), 4.

31 Fussilet (41), 41

32 Bakara (2), 2; Secde (32), 2.

33 Hûd (11), 1.

34 Zümer (39), 23. 
ifadeleriyle nitelendirilmekte, ona uyulmas1 ${ }^{35}$ ve parça parça değil, tamamına iman edilmesi istenmektedir. ${ }^{36}$ Bu sifatlara sahip Kur'ân'ın esas olarak yazılı metnine "kitap" denilmektedir; fakat "Filan kitap ezberimdedir." örneğinde olduğu gibi, bu isim, onun ezberde olan / telaffuz edilen şeklini de kapsamaktadır. Şüphe yok ki, bunların hepsinin altında manaya delâlet muteberdir. Sadece manaya "kelâm" denilebilirse de, kitap denilmesi örften değildir. O halde en mütekamil anlamda kitap, ilâhi kelamın ibaresinden (sözlü veya yazılı metin) ve o ibarenin delalet ettiği manadan [tefsir değil] oluşan bütündür. ${ }^{37}$ Medine döneminin hemen başında vahyedilen ${ }^{38}$ Bakara Suresi'nde Kur'ân'dan "kitap" ismiyle söz edilmesi (2'nci ayet), ilâhî kelamın kısmen de -ibare-mana bütünlüğü içerisinde- bu isimle isimlendirilebileceğini göstermektedir. Zira bu sureden sonra inen birçok sure bulunmaktadır. İlâhî kitaba bu ismin verilmesi, sözlü aktarıma dayanan şifahi kültür ortamında orijinal bir şeydir ve Kur'ân metni, Arap kültüründeki sözlü dönemle yazılı dönem arasında ayırıcı bir halka mesabesindedir. ${ }^{39}$

Kur'ân'ın isimleri ve sıfatları elbette bunlarla sınırlı değildir. Değiş̧ik ayetlerde yer alan nitelendirmelere göre Kur'ân, doğru ile yanlışı birbirinden ayırmaktadır (el-Furkân), ${ }^{40}$ insanlar için bir uyarıdır, ${ }^{41}$ ögüuttür, ${ }^{42}$ açıklamadır, ${ }^{43}$ bütün insanlara bir bildiridir (belâğ) ${ }^{44}$ inkârcıllı̆̆a, kalp bozukluğuna ve ahlâkî kötülüklere karşı şifadır, ${ }^{45}$ [doğruyu yanlıştan] ayırıcı veya hüküm verici bir söz (kavlün fasl) olup, saçmalık değildir, ${ }^{46}$ kesin bir delildir (burhân), ${ }^{47}$ önceki ilahi kitaplar gibi, ${ }^{48}$ hikmettir, ${ }^{49}$ yine onlar gibi, ${ }^{50}$ aydınlatıcı bir nurdur, ${ }^{51}$ diğer vahiyler gibi, ${ }^{52}$ Allah'ın / Rabbin insanlara mesajıdır (risâ-

35 En'âm (6), 155.

36 Bakara (2), 85.

37 Yazır, Hak Dini Kur'ân Dili, I, 162-63.

38 Cerrahoğlu, Tefsir Usulü, 87; Muhammed Esed, Kur'ân Mesajı, 3.

39 Nasr Hâmid Ebû Zeyd, İlahi Hitabın Tabiatı Metin Anlayışımız ve Kur'ân İlimleri Üzerine, çev. M. Emin Maşalı, Ankara: Kitâbiyât, 2001, s. 79.

40 Furkân (25), 1.

41 Enbiyâ (21), 50; Hâkka (69), 48; Abese (80), 11; Tekvîr (81), 27-28.

42 Âl-i İmrân (3), 138; Yûnus (10), 57.

3 Âl-i İmrân (3), 138.

44 İbrâhîm (14), 52.

45 Yûnus (10), 57; İsrâ (17), 82. Açıklama için bkz. er-Râzî, Mefâtîhu'l-gayb, II, 15.

46 Târık (86), 13-14. Açıklama için bkz. er-Râzî, Mefâtîhu'l-gayb, II, 15.

47 Nisâ (4), 174.

48 Zuhruf (43), 63.

49 İsrâ (17), 39.

Mâide (5), 44, 46; En'âm (6), 91.

1 Nisâ (4), 174; A'râf (7), 157; Şûrâ (42), 52.

52 A'râf (7), 68, 79, 93; Ahzâb (33), 39; Cin (72), 28. 
let), ${ }^{53}$ Allah'ın ipidir. ${ }^{54}$ En önemlisi, daha önceki kutsal kitaplarınki gibi, ${ }^{55}$ Kur'ân'ın ayetleri de Allah'ın kelamıdır. ${ }^{56}$ Cebrail bu ayetleri Hz. Peygamber'in kalbine apaçık bir Arapça lisanla indirmiștir. ${ }^{57}$ Ona indirilen bu kitap, esas itibariyle Allah katındaki Ana Kitap'ta (Ümmü'l-kitâb) bulunmaktadır. ${ }^{58}$ Diğer bir anlatımla o, "korunan bir levha" (levh mahfûz), ${ }^{59}$ yine aynı anlamda, "iyi korunan bir kitap" (kitâb meknûn) ${ }^{60}$ ya da "değerli, yüce ve tertemiz sayfalar" içerisinde bulunan, onurlu ve faziletli elçiler [melekler] aracılığıyla vahyedilmiş, dileyenin öğüt alabileceği şerefli ve değerli bir Kur'ân'dır. ${ }^{61}$ Netice olarak o, Allah'tan başkasının katından değildir, ${ }^{62}$ dolayısıyla vahiy ürünüdür ${ }^{63}$ ve Alemlerin Rabbi tarafından indirilmiştir. ${ }^{64}$

\section{b. Kaynağı}

Ayetlerinin "Allah sözü" olarak nitelendirilmesi ve Cebrail tarafından "Hz. Peygamber'in kalbine vahyedildiğinin" belirtilmesi ve yukarıda temas ettiğimiz diğer özellikleri, Kur'ân'ın kaynağının ilâhî olduğunu hiçbir şüpheye yer bırakmayacak biçimde ortaya koymasına rağmen, "Allah'ın konuştuğu bir dili (lisanı) var mıdır? Şayet varsa, bu dil Arapça mıdır? O, insanlarla sözlü iletişim kurmak için gerçekten bir dile ihtiyaç duymakta mıdır?" vb. sorula-

\footnotetext{
Mâide (5), 67.

Âl-i İmrân (3), 103. Açılama için bkz. er-Râzî, Mefâtîhu'l-gayb, II, 15.

Bakara (2), 75

Tevbe (9), 6; Fetih (48), 15

Şuarâ (26), 193-195.

58 Zuhruf (43), 4. Bu ayette "Ümmü'l-kitâb" birleșik kelimesiyle levh-i mahfûz kastedilmektedir. Bkz. Nasr b. Muhammed b. Ahmed Ebu'l-Leys es-Semerkandî, Tefsîru's-Semerkandî (Bahru'lulûm), Beyrut: Dâru'l-fikr, 1416/1996, III, 251; er-Râzî, Mefâtîhu'l-gayb, XXVII, 167.

59 Burûc (85), 21-22.

60 Vâkıa (56), 77-78. Bu ayetteki "kitâb meknûn" ifadesiyle levh-i mahfûzun kastedildiği genel olarak kabul edilmektedir. Bkz. Ebu'l-Hasan Ali b. Muhammed el-Mâverdî el-Basrî, en-Nüket ve'l-uyûn (Tefsîru'l-Mâverdî), thk. es-Seyyid Abdulmaksûd b. Abdirrahim, Beyrut: Dâru'l-kütüb el-ilmiyye, 1412/1992, V, 463; el-Kâdî Ebû Saîd Abdullah Ebû Ömer b. Muhammed eş-Şîrâzî elBeydâvî, Envâru't-tenzîl ve esrâru't-te'vîl, Beyrut: Dâru'l-fikr, 1416/1996, V, 292.

61 Abese (80), 11-16. Bu surenin ilk ayetlerinde (1-10), Müslüman bir âmâyı ihmal ederek Kureyș ileri gelenleriyle ilgilendiği için Hz. Peygamber eleştirilmektedir. 11-16'ncı ayetlerde ise, ilâhî kitabın bu uyarıların yer aldığı bölümü övülmektedir. Şayet Kur'ân'ın bir bölümü Allah katında bu kadar değerliyse, diğer bölümlerinin de aynı derecede değerli olduğunu rahatlıkla söyleyebiliriz. Açıklama için bkz. Ebû Ca'fer Muhammed b. Cerîr et-Taberî, Câmiu'l-beyân an te'vîl-i âyi'l-Kur'ân, Beyrut: Dâru'l-fikr, 1408/1988, XXX, 53; el-Mâverdî, en-Nüket ve'l-uyûn, VI, 203; Ebû Ali el-Fadl b. el-Hasan et-Tabresî,Mecmeu'l-beyân fí tefsîri'l-Kur'ân, Beyrut: Dâru'l-fikr,1414/ 1994, X, 240; Ebu'l-Fidâ' İsmail İmâdüddin b. Ömer b. Kesîr, Tefsîru'l-Kur'âni'l-Azîm, thk. M. İbrahim el-Bennâ vd., Kahire: Dâru'ş-Şa'b, tarihsiz, VIII, 344.

62 Nisâ (4), 82.

63 En'âm (6), 19; Yûsuf (12), 3; Ŝurâ (42), 7.

64 Şuarâ (26), 192; Secde (32), 2; Vâkıa (56), 80; Hâkka (69), 43.
} 
ra açık bir cevap teşkil etmediğinden, onun metninin bizzat Allah tarafından oluşturulduğunu / kurgulandığını garanti etmemektedir. Bundan ötürü usulcüler, Kur'ân metninin hem lafız, hem de mana olarak mı Allah'a ait olduğu, kendisine ilka edilen manaları vahiy meleği Cebrail'in mi Arapça'ya çevirdiği, yoksa Cebrail tarafından kalbine ilka edilen manaları Hz. Peygamber'in mi Arap dilinde ifade ettiği konusunda son derece şiddetli tartışmalar yapmışlardır. Yaygın olan kanaat, Kur'ân metninin bizzat Allah tarafindan oluşturulduğu yönündedir. ${ }^{65}$ Kim tarafindan oluşturulursa oluşturulsun, Kur'ân metninin mevcut haliyle Allah tarafından övüldüğü bir gerçektir. Zira yukarıda zikrettiğimiz nitelendirmeler, hiç de sırf anlama yönelik övgüler gibi görünmemektedir. Aksine ilâhî kelamın sihir, ${ }^{66}$ beşer sözü, ${ }^{67}$ 1srarla da şair sözü ${ }^{68}$ veya şeytan sözü olduğunu söyleyen ${ }^{69}$ müşrikler ve diğer gayr-i müslim unsurlar şiddetle reddedilip, kınanmakta, onun Peygamber tarafindan uydurulmadığı oldukça açık bir biçimde vurgulanmaktadır: 'Onu kendisi uydurdu.' mu diyorlar? Tam aksine o, Rabbinden [gelen] haktır. ${ }^{70}$ Şayet bize karşı birtakım yalanlar uydursaydl, biz onun gücünü [lafzen: să̆, săg el] giderirdik ve şah damarını keserdik. ${ }^{71}$ Üstelik mevcut haliyle Kur'ân'ın bizzat Allah tarafından koruma altına alındığı haber verilmektedir: Uyarıyı [Kur'ân'ı] kesinlikle biz indirdik, onu koruyanlar da elbette yine biziz. ${ }^{72} \mathrm{Bu}$ ayetten anlaşılmaktadır ki, nasıl ki, ilâhî irade vahyin aracısı konumundaki Hz. Muhammed'in davranışlarını denetim altında tutmuş, bu bağlamda bir âmâdan yüzünü çevirmesini dahi şiddetle eleştirmişse, ${ }^{73}$ aynı şekilde Kur'ân'ın vahiy dönemindeki yazılışını da -şeklen değilse bile manen- kontrol altında tutmuştur. Hz. Peygamber onun yazımı konusunda büyük bir duyarlılık göstermiş, kendisine nasıl vahyedilmişse vahiy kâtiplerine öylece yazdırmıştır. ${ }^{74}$ Şayet metnin -uzatma harflerinin yazımında

65 Geniş bilgi için bkz. ez-Zerkeşî, el-Burhân, I, 229-30; es-Suyûtî, el-ìtkân, I, 124-26.

66 Sebe (34), 43; Zuhruf (43), 30-32; Ahkâf (46), 7.

67 Müddessir (74), 24-26.

68 Enbiyâ (21), 5-6; Hâkka (69), 41.

69 Tekvîr (81), 25.

70 Secde (32), 3. Ayrıca bkz. Yûnus (10), 38; Hûd (11), 13, 35; Furkân (25), 4; Şuarâ (26), 210212; Ahkâf (46), 8.

${ }^{71}$ Hâkka (69), 44-46.

72 Hicr (15), 9.

73 Abese (80), 1-4.

74 Geniş bilgi için bkz. ez-Zerkeşî, el-Burhân, I, 229-30; es-Suyûtî, el-i̇tkân, I, 162-63; ez-Zerkânî, Menâhilüll-irfân, I, 177-79; M. Abdullah Derrâz, Medhal ile'l-Kur'âni'l-kerîm, trc. M. Abdulazim Ali, Kuveyt: Dâru'l-kalem, 1414/1994, s. 33-34; Subhî es-Sâlih, Mebâhis fí ulûmi'l-Kur'ân, ettab'atü'r-râbia, Beyrut: Dâru'l-ilm li'l-melâyîn, 1965, s. $69-70$ (Türkçe'si için bkz. Subhî es-Sâlih, Kur'ân İlimleri, çev. M. Said Şimşek, Konya: Hibaş Yayınları, tarihsiz, 58-59); Cerrahoğlu, Tefsir Usûlü, 53-54; Suat Yıldırım, Kur'ân-ı Kerîm ve Kur'ân İlimlerine Giriş, 2. baskı, İstanbul: Ensar Neşriyat, 1985, s. 33-34; Muhsin Demirci, Kur'ân Tarihi, İstanbul: İFAV, 1997, s. 126-28. 
kâtiplerin yaptıkları tercihler vb. gibi, anlamı çok da etkilemeyen- şeklinde değilse bile ilâhî mesajı yansıtan genelinde Allah'ın onaylamadığı bir durum ortaya çıksaydı, Allah ona yeni bir vahiyle müdahale ederdi; zira bu, $\mathrm{Hz}$. Peygamber'in davranışını düzeltmekten çok daha önemli ve hayati bir konudur. İlave olarak, eğer Allah Kur'ân'ın manası ve mesajı kadar metninin de üstünlüğüne güvenmeseydi, onun bir benzerini getirebilmeleri için insanlara meydan okumazd1. ${ }^{75}$

Görülmektedir ki, Mekke döneminin başlarından itibaren gayr-i müslim unsurlar, ilâhî kitabın kaynağı konusunda, onu karalamak suretiyle insanların Müslüman olmalarını engellemeye matuf şüphe ve tereddütler oluşturmaya çalışmışlar, Kur'ân'da da bunlara gerekli cevaplar verilmiştir. Son asırlarda müsteşriklerin (doğu bilimci, oryantalist) de benzer faaliyetler içerisine girerek, gerek Hz. Peygamber'in peygamberliği, gerekse Kur'ân'ın kaynağ1 konusunda çeşitli fikirler ileri sürdükleri görülmektedir. Bunlar içerisinde, Mekke dönemi putperestleri gibi, ilâhî kitabın kaynağının eski Arap şiiri olduğunu iddia edenler bulunduğu gibi, Hz. Muhammed'in, Yahudi, Hıristiyan ve Süryani kültüründen etkilenerek, Kur'ân'ın büyük bölümünü özellikle ilk iki toplumun din adamlarından edindiği bilgilerle telif ettiğini ileri sürenler de vardır. Bazıları Mekkeli Haniflerin tek Allah inancına dayalı inanç ikliminin Kur'ân'a kaynaklık etmiş olabileceğini, diğerleri de Hz. Muhammed'in uzlete çekilerek derin dini düşüncelere dalması neticesinde Kur'ânî gerçekleri keşfetmesinin mümkün olduğunu ortaya atmıştır. Mantık ve bilimsellik ölçülerini aşmakta sınır tanımayan bu müsteşriklerden bir kısmı, 9-12 yaşlarında bir çocuk iken Hz. Peygamber'in Rahip Bahira ile görüşmesini, daha sonraki dönemlerde ticari seferlere çıkmasını, Mekke'ye gelen ticaret adamları ile yaptığı görüşmeleri bile Kur'ân'ın kaynă̆ı olarak gösterebilmişlerdir. Müsteşriklerden bir kısmı, Kur'ân kıssalarına halk arasında dolaşan söylentilerin, destanların, hikayelerin ve bunlarla ilgili fikirlerin kaynaklık ettiğini savunurken, diğer bir kısmı ise, Mekke'nin kenar mahallelerinde ikamet edip, şarap satıcılığı ve hamallıkla geçimlerini sağlayan Romalı veya Habeşistanlı maceracı basit kimselerden edindiği fikirlerin Kur'ân'ın kaynağı olduğunu ileri sürmüştür. İslâm alimleri, çoğu gülünç denecek kadar basit, bir o kadar da kasti olan bu görüşleri çürüterek, Kur'ân'ın kaynağının ilâhî olduğu temasını özenle işlemişlerdir. ${ }^{76}$ Bununla birlikte, yukarı-

75 Bakara (2), 23; Hûd (11), 13; İsrâ (17), 88; Tûr (52), 33-34. İlgili açıklama için bkz. Subhî esSâlih, Mebâhis fĩ ulûmi'l-Kur'ân, 46-47 (Türkçe'si için bkz. Kur'ân İlimleri, 38-39).

76 Bu iddialar ve cevapları ile ilgili olarak geniş bilgi için bkz. Abdullah Draz, Kur'ân'ın Anlaşılmasına Doğru, cev. Salih Akdemir, Ankara: Mim Yay., 1983, s. 132 vd.; Subhî es-Sâlih, Mebâhis fî ulûmi'l-Kur'ân, 44-46 (Türkçe'si için bkz. Kur'ân İlimleri, 36-38); Salih Akdemir, Müsteşriklerin 
da da belirttiğimiz gibi, Kur'ân, kendinden önceki kutsal kitapları tasdik ettiğini, yani onlarla aynı ilâhî mesajları getirdiğini açık bir biçimde ilan etmektedir. Ayrıca pek çok ayetin bir sebebe istinaden indiği de muhakkaktır. Bunlar, o mesaj ve ayetlerin ilâhî olmadığını gösteren unsurlar olarak değil, onların ifade biçimlerini etkileyen faktörler olarak görülebilir.

\section{c. Mana ve Metinden İbaret Oluşu}

Buraya kadar verdiğimiz bilgiler göstermektedir ki, usulcüler Kur'ân'ın manası kadar metnine de büyük bir önem vermektedirler; zira onlara göre bu kitap, okunuşuyla ibadet edilen kutsal bir metindir. ${ }^{77}$ ìlâhî kelamın sırf manasına Kur'ân veya Kitap denilip denilemeyeceği meselesini ele alan M. Hamdi Yazır'ın (1942), "Sırf manadan ibaret bir kitap, bir Kur'ân tasavvuru mümkün değildir."”8 dedikten sonra, bu görüşünü savunmak üzere yaptı̆̆ 1 açıklama, geleneksel bakış açısını yansıtması bakımından oldukça önemlidir:
Medlûl-i mahz olan mana ile zihinde maksut olan suver-i elfâzı, kelâm-1 nefsîyi fark edemeyenler, kitabı sadece manadan ibaret imiş gibi teveh- hüm edebilirler. Lakin mesele ilm-ü fen ve bilhassa ilmünnefs nazarıyla mütâlaa edildiği zaman mükemmel, güzel, metin denilebilen efkâr ve maânînin suver-i elfaz ile öyle derin bir iştibak ve irtibatı görülür ki, lisan dediğimiz o suver-i lafzıyeyi alıverecek olursanız, fikirde, manada hiçbir metanet ve itkan bulamazsınız. O yüksek maânî ve efkârdan nişane göre- mezsiniz. Yani nazım yalnız ahara değil, mütefekkirin kendi kendisine bile tefhim ve temyiz-i mamada mühim bir vasıtadır. Zaten böyle olmasa idi, lisan ve kitabetin terakkiyat-1 fikriye ve maneviyede büyük bir ehemmiye- ti kalmazdi. ${ }^{79}$

O halde mevcut haliyle -Mushaf olarak da isimlendirilen- ${ }^{80}$ Kur'ân, tamamlanmış mükemmel bir ilâhî kitaptır. ${ }^{81}$ Bu algılayış biçimi, “... Hz. Peygamber ve çevresi daha fazla yaşasaydı, vahyi şekillendirmeyi sürdürecekleri düşünülürse, ylllar ve şartlar değiştikçe vahyin potansiyel olarak değişebi-

Kur'ân-ı Kerim ve Hz. Muhammed (sav)'e Yaklaşımları, AÜIFD, Ankara, 1989, c. XXXI (ss. 179210), s. 193 vd.; Demirci, Kur'ân Tarihi, 77-91.

77 ez-Zerkânî, Menâhilü'l-irfân, I, 20, 427-28; Adnân Muhammed Zarzûr, Ulûmu'l-Kur'ân medhal ilâ tefsîri'l-Kur'ân ve beyânü i'câzihî, et-tab'atü's-sâlise, Beyrut: el-Mektebü'l-İslâmî, 1412/1991, s. 46-48.

78 Yazır, Hak Dini Kur'ân Dili, I, 63.

79 Yazır, Hak Dini Kur'ân Dili, I, 163.

80 ez-Zerkeşî, el-Burhân, I, 282; es-Suyûtî, el-İtkân, I, 162.

Bu isimlendirmeyi, Zerkeşî İbn Mes'ûd'a, Suyûtî ise Ebû Huzeyfe'nin Mevlâsına isnat etmektedir. Her iki görüşün ortak noktası, Kur'ân'ın Mushaf şeklinde adlandırılmasının Habeşlilerden ilham alınarak yapıldığının belirtilmesidir. 
lirlik özelliği taşıyan bir bakış açısı olarak görülebileceği"82 türünden değerlendirmelere kapılarını sıkı sıkıya kapatmaktadır. Çünkü Hz. Muhammed'in vefatıyla birlikte ilâhî kitaba girebilecek özellikteki vahiy olgusu sona ermiştir; mevcut haliyle Kur'ân-1 Kerim yeterlidir; şayet öyle olmasaydı, Allah, Peygamberine daha fazla ömür takdir eder, yeterli miktarda vahiy gönderir ve mesajını tamamlardı. O halde, bahsi geçen şekilde fikir yürütmenin iler tutar ve makul bir tarafı yoktur. Bununla birlikte, bazı eski problemlerin günümüzde artık iyice şekil değiştirdiği, üstelik karşılaştı̆̆ımız birçok yeni problemin ve çözümlerinin motamot Kur'ân'da bulunmadığı da bir gerçektir. Klasik usulü hiç benimsemese dahi -kaldı ki, yüzyılların birikimi olan bir metodolojiyi tamamen reddetmek, imkansiz derecesinde zordur-, böylesi durumlarda bir Kur'ân araştırmacısının yapması gereken, kanaatimizce, "Allah yeni bir vahiy gönderseydi, şu anlamda bir ayet gönderirdi veya Peygamber yaşasaydı, bu problemi şöyle çözerdi.” diyerek, aslında kendi düşüncesinin ürünü olan çözümü Allah veya Peygamber'le özdeşleştirmek gibi son derece tehlikeli bir yola kesinlikle girmemektir. Bu tür yaklaşımlara sadece tutarlı ve makul olmaması açısından değil, aynı zamanda fikri farklılıkları daha baştan önleyeceği, tabiatı gereği müsamahakâr olmayacağı, dolayısıyla gereksiz yere gerilim ve çatışmaya yol açacağı göz önüne alınarak da iltifat edilmemelidir. Bu noktada eski müfessirlerin, bir ayeti tefsir ederken, ulaşabildikleri bütün argümanları toplayarak değerlendirmelerini yaptıktan sonra "Neyi kastettiğini en iyi bilen Allah'tır." (Allâhu a'lem bi murâdihî) demeleri, gerçekten büyük bir tevazu örneği olarak karşımıza çıkmaktadır. Zira böylece, bir ayetin gerçek anlamının, vahyin Arapça'ya dönüştürülmeden önceki anlamı olduğuna, yapılan araştırma neticesinde ortaya çıkan görüşün müfessirin kendi görüşü olduğuna dikkat çekilmiş olmaktadır.

\section{d. Arap Kültürüyle iliş̧kisi}

Kur'ân, kendisinin Arapça olduğuna, ${ }^{83}$ hatta apaçı bir Arapça ile indirildiğine $^{84}$ özel bir vurgu yapmaktadır. Dolayısıyla, onun metninin oluşumunda

81 Ebu'l-Kâsım Cârullah Mahmûd b. Ömer b. Muhammed ez-Zemahşerî, el-Keş̧̧âf an hakâiki gavâmid't-Tenzîl ve uyûni'l-ekâvîl fì vücûhi't-te'vîl, thk. Muhammed Abdusselam Şahin, Beyrut: Dâru'l-kütüb el-ilmiyye, 1415/1995, I, 42-43.

82 Üzeyir Ok, "Kur'ân Okumanın 'Metalinguistik' Yapısı: Bir Sosyokültürel Aktivite Teorisi Yaklaş1mı", İslâmiyât Üç Aylık Araştırma Dergisi, cilt: VI, sayı: 4, Ekim-Aralık 2003 (ss. 151-170), Ankara: Özkan Matbaacillk, 2004, s. 158.

83 Yûsuf (12), 2; Ra'd (13), 37; Tâhâ (20), 113; Zümer (39), 28; Fussilet (41), 3, 44; Şûrâ (42), 7Zuhruf (43), 3; Ahkâf (46), 12.

84 Nahl (16), 103; Şuarâ (26), 193-195. 
Arapça'nın dilbilimsel ve anlatımsal özelliklerinin kullanılmaması, bu dilin tarihi-kültürel temelini oluşturan Arap kültürünün ve edebiyatının enstrümanlarından yararlanılmaması düşünülemez. Bu bakımdan Kur'ân'ın layıkıyla anlaşılması, temel olarak İslâm'dan hemen önceki Arapça'nın, bütün enstrümanlarıyla cahiliye dönemi edebiyatının, yine o dönemin sosyal ve kültürel yapısının iyi bilinmesi ile mümkün olabilir. Ancak İslâmî ilimlerle ilgilenen herkes bilir ki, salât ve zekât gibi bazı kavramlara Kur'ân yeni anlamlar yüklemiştir. Tabir caizse, terim anlamları itibariyle bunlar, eski kültürel köklerinden önemli ölçüde kopartılmış ve dönüştürülmüsş kavramlardır. Aynı durum birçok ayetin anlam dokusu için de geçerlidir. Ĕger Kur'ân metnini sırf Arap dili ve kültürü biçimlendirseydi, yeminlerde deve, kılıç, savaş, soy, şeref, haysiyet vb. öğelerin kullanılması daha makul olurdu; zira bunlar vahiy dönemindeki Arap edebiyatının enstrümanlarını oluşturuyordu. ${ }^{85}$ Oysa özellikle Mekkî ayetlerdeki yeminlerde kültürel ve edebi yükseklik hemen kendini hissettirmektedir: Kaleme ve yazdıklarına yemin olsun. ${ }^{86}$ Kınayan nefse and olsun. ${ }^{87}$ Yemin olsun, burçlar sahibi göğe. ${ }^{88}$ And olsun, güneşe ve kuşluğuna, onu izlediği zaman aya, (...) göğe ve onu inşa edene, yere ve onu döşeyene/genişletene, cana ve ona [yapabileceği] kötülüğünü ve iyiliğini ilham edene. ${ }^{89}$ Gerek yemin edilen şeyler, gerekse bu yeminlerin amaçları, cahiliye dönemi Arap kültüründe üzerine yemin edilen nesnelere ve gözetilen amaçlara genellikle yabancı olgulardır. ${ }^{90} \mathrm{O}$ halde, metninin Arapça oluşuna sığınarak, biraz da Arapçılıktan etkilendiği izlenimi veren bir bakış açısıyla, Kur'ân'ın Arap kültürünün ürünü olduğunu söylemek, ${ }^{91}$ amacını aşan ve gerçekten abartılı bir iddiadır. Fakat bizim bu ifademizden, Kur'ân'ın kültür ve olgudan tamamen kopuk bir metin olduğu sonucu da çıkarılmamalıdır. Bizim vurgulamak istediğimiz, bir kültürün ürünü olmakla, o kültürden yararlanmak ve onun -özellikle dilsel- enstrümanlarını kullanmak arasındaki ince çizgidir.

Öte yandan, getirdiği temel ilkeler, gözettiği genel amaçlar ve içerdiği konular, Kur'ân'ın, cahili Arap kültürünün bir ürünü değil de "dönüştürücü-

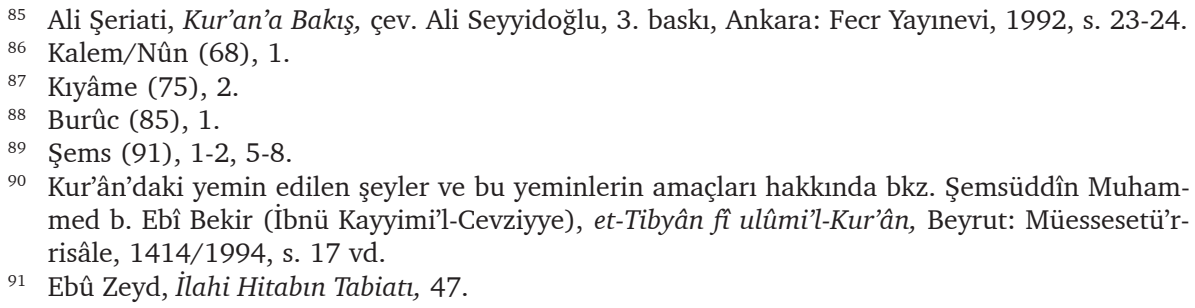

90 Kur'ân'daki yemin edilen şeyler ve bu yeminlerin amaçları hakkında bkz. Şemsüddîn Muhammed b. Ebî Bekir (İbnü Kayyimi'l-Cevziyye), et-Tibyân fî ulûmi'l-Kur'ân, Beyrut: Müessesetü'rrisâle, 1414/1994, s. 17 vd.

91 Ebû Zeyd, İlahi Hitabin Tabiatı, 47. 
sü", yani "İslâmîleştiricisi ve medenileştiricisi" olarak algılanmasının daha doğru olduğunu göstermektedir. Kur'ân, Puta tapıcılı̆̆ın ve basit düzeydeki kabile kurallarının hakim olduğu, haklının değil de kabiledaşın desteklendiği, dolayısıyla birçok ahlâk ilkesini çiğnemenin cesaret ve yiğitlik sayıldığı bir topluma, tevhit inancını, Allah'a ibadet prensibini, güzel ahlâk ve adalet ilkelerini getirmiş, bu değerleri özümseyen ve onlarla donanan bir insan modeli önermiş, karşılıklı sevgi, saygı ve barışa dayalı bir toplum yapısı teklif etmiştir ki, bireysel mutluluğun ve toplumsal huzurun anahtarı olan bu değerleri burada ayrıntılarıyla tadat etmeyi gereksiz buluyoruz. ${ }^{92}$ Kur'ân, dinsel değer yargisı ifade eden bu kavramları cahiliye kültüründen ödünç almamış, bilakis bunları ya eski kültürden dönüştürerek içlerini yeni öğelerle doldurmuş, en azından yeni dinin ilkelerine uygun anlam örgüsüne kavuşturmuş, ya da yeniden inşa etmiştir. Cömertlik, cesaret, vefâ, sadakat gibi kavramlar bunlardan ilkine, İslâm, iman, küfür gibi kavramlar ise ikincisine örnek teşkil etmektedir. ${ }^{93}$ Kur'ân'1 kültürün ürünü ilan ederken, bu kavramların İslâm'dan önceki anlamlarından çok daha öte anlamlar kazandığını unutmamak gerekir. Bu kavramları duyan bir cahiliye Arabı, bunlara hangi anlamların yüklendiğini öğrenmesi gerekir; aksi halde bunları ya yanlış anlar, ya da hiç anlamaz. Bu da gösteriyor ki, Kur'ân'ın Arap kültürünün bir ürünü olduğu varsayımına dayalı "edebî tefsir metodu", ${ }^{94}$ bazı ayetleri anlamaya elverişli olsa bile, ilâhî kitabın bütününü yorumlamaya elverişli bir metot olmaktan uzaktır. Ancak bu söylediklerimiz, Kur'ân'da geçen çok sayıdaki kelime ve kavramın anlamını tespit edebilmek için cahiliye kültürüne müracaat etmemiz gerektiği gerçeğini değiştirmez. Klasik usulde ayetler açıklanırken, kelimelerin sözlük anlamlarına öncelik verilmesi, cahiliye şiirindeki kullanılışlarına başvurulması, anlatımdaki edebi inceliklerin bu şiirle paralellikler kurularak açıklanması, ${ }^{95}$ cahili Arap kültürüne gerektiği kadar önem verildiğinin açık şahididir. Bizim söylemek istediğimiz, bundan fazlasının fuzuli olacağı, dolayısıyla amaca hizmet etmeyeceğidir.

92 Konuyla ilgili kapsamlı bir araştırma için bkz. Fazlur Rahman, Ana Konulartyla Kur'ân, çev. Alpaslan Açıkgenç, 2. baskı, Ankara: Fecr Yay., 1993, s. 65 vd.

93 Geniş bilgi için bkz. Toshihiko İzutsu, Kur'ân'da Dinî ve Ahlâkî Kavramlar, çev. Selâhattin Ayaz, 2. baskı, İstanbul: Pınar Yayınları, 1991, s. 71 vd.

94 Bu metot ve taraftarları hakkında bkz. Emîn el-Hûlî, Kur'ân Tefsirinde Yeni Bir Metot, çev. Mevlüt Güngör, İstanbul: Bayrak Matbaası (kişisel yayın), 1995, s. 66 vd.; Muhammed Hüseyin ezZehebî, et-Tefsîr ve'l-müfessirûn, et-tab'atü's-sâdise, Kahire: Mektebetü vehbe, 1416/1995, II, 588 vd.; Cerrahoğlu, Tefsir Usulü, 311-19; aynı yazar, Tefsir Tarihi, Ankara: Dï Yay., 1988, II, 467 vd.; Turgut, Tefsir Usulü, 306-17.

95 Örnek için bkz. es-Suyûtî, el-i̇tkân, II, 348 vd. 


\section{e. Üslubu}

Arap dilinde "usul, yol, metot, tarz, biçim, biçem / stil" gibi anlamlara gelen üslup kelimesi, bir dil terimi olarak, "konuşmacının, söz dizimini kurmada ve lafızlarını seçmede izlediği söz söyleme biçimi" veya "konuşmac1nın, sözünün anlamlarını ve amaçlarını kurgularken izlediği kendine has söz söyleme usulü" ya da "konuşmacının [yalnızca] kendine ait olan söz söyleme karakteri veya tekniği" şeklinde tanımlanmaktadır. Bir tefsir usulü terimi olarak Kur'ân'ın üslubu (üslûbu'l-Kur'ân), "Kur'ân'ın, söz dizimini kurmada ve lafızlarını seçmede izlediği kendine özgü tarzı" anlamında kullanılmaktadır. Bu tanımlardan da anlaşılacağı gibi, üslup, [bir dildeki] kelimelerden ve [onların] bileşiminden (terkîb) çok farklıdır. Bunlarla üslup arasındaki fark, terzilerin kullandıkları makine, kumaş, iplik vb. alet ve teçhizat ile dikim esnasında gösterdikleri hüner arasındaki fark gibidir. Nasıl ki, iki farklı terzinin ortaya koyduğu ürünler, onların malzeme seçimlerinden dikimlerine kadar her aşamada belirleyici olan kabiliyet, bilgi, beceri, ustalık ve sanatlarındaki farklılıktan dolayı birbirinin aynısı olmazsa, aynı şekilde iki farklı yazarın -aynı dili kullansalar bile- ortaya koyacakları eserler de farklı olacaktır; zira kelime, kavram ve tamlamaları kullanmadaki, anlatım ve ifade tarzındaki maharet ve zevkleri farklıdır. ${ }^{96}$ Şu halde dil, kişinin düşüncesini anlatmak için yararlandığı gereçtir; üslup ise, bazı sonuçları gerçekleştirebilmek için kişinin bu gereç içinde yaptığı seçmelerden doğmaktadır. Bu tarif doğrultusunda, dilin bütün görünüşleri, yani, sesleri, biçimleri, kelimeleri ve yapıları üslup kavramı ile ilişkilendirilmektedir. ${ }^{97}$ Bu açıklamalar ışığında Kur'ân'ın üslubunun, "onun telifinde izlenen ince zevk, sanat ve teknikten, anlatımına rengini veren ifade tarzlarından" ibaret olduğunu söyleyebiliriz.

Zerkeşî (794/1392), Kur'ân'ın üslubunun, bir kasidenin en can alıcı beyti, [tepesindekiler hariç] yaprakları dökülen [dolayısıyla bir sütun gibi dümdüz ve pürüzsüz hale gelen] uzun bir hurma ağacının başlangıç kısmı, bir yazılı metnin en ilgi çekici / en güzel bölüntüsü, bir kolyenin ortasındaki mücevher, bir tacın incisi, bir irisin ortasındaki gözbebeği gibi olduğunu vurguladıktan sonra, bu ilmin şerefli ve büyük bir yere sahip bulunduğunu belirtmekte, fakat bu ilmi layıkıyla öğrenenlerin azlığından yakınmaktadır. Oysa ona göre, Kur'ân'ın [gönderilmesindeki] en büyük amaç, ondaki sanatsal

ez-Zerkânî, Menâhilü'l-irfân, II, 552-54.

97 Meydan Larousse Büyük Lügat ve Ansiklopedi, İstanbul: Meydan Yay., "Üslupbilim" maddesi, XII, 488. 
üslup ve belâgatın ortaya çıkmasıdır; onun üslubu şiirden daha hassas / ince, denizden daha büyük, sihirden daha şaşırtıcıdır. İşte bu üslup, Kur'ân'ın sırlarına vakıf olunmasını sağlamaktadır. Yine bu üslup, ilâhî metnin mu'ciz olduğunu da garanti etmektedir; çünkü ona bu güzel telifi, maharetli yapıyı / oluşumu, içerdiği tatlılığ 1 ve onu yücelten üstün zarafeti kazandıran -ki, bu da anlatımda kolay, açık, hoş ve akıcı sözler kullanılması sayesinde gerçekleşmektedir- bu üsluptur. Usulcüler, üstün üslup özelliklerini Kur'ân'ın yalnızca manasında mi, yoksa hem lafzında, hem de manasında mı aramak gerektiği konusunda farklı görüşler ileri sürmüşlerdir. Birinci görüşü kabul edenler olsa da, onların kahir ekseriyetine göre, ilâhî kitap hem lafızları, hem de manaları itibariyle üstün üslup ve belagat özelliklerine sahiptir. Doğrusu da budur; zira lafız sözün (el-kelâm) malzemesidir, o olmadan üslup ve belagat tekniklerinden bahsetmek mümkün değildir. ${ }^{98}$

Hem lafzı, hem de manası itibariyle üstün üslup özelliklerine sahip olduğuna göre, Kur'ân'ın te'kîd (pekiştirme), hazf, takdim, tehir, teşbih (benzetme), istiâre (metafor), tevriye, îcâz (sözü kısaltma), itnâb (söz katma), hitapta soru-cevap metodu, kelâm edebi, azaptan ziyade rahmete öncelik verme gibi edebiyat ve anlatım enstrümanları onun üslup özellikleri arasında yer almaktadır. ${ }^{99}$ İlave olarak, ilâhî hitabın lafızları gerek ses nizamları, gerekse lügavi güzellikleri itibariyle akıcı, çekici ve harikadır. ${ }^{100}$ Bunlara, ilâhî mesajın amacını gerçekleştirmek için seçilen kelimelerin köken, sarf ve anlam yönünden aynı üslup güzelliklerine sahip olmalarını da ekleyebiliriz. Gerçekten, Arapça'yı bilen bir kişi, Kur'ân'ı okumaya veya dinlemeye başladığında, sözdizimi itibariyle onun Arapça olduğunu, bu dilin cahiliye dönemine ait kelime ve kavramlarını kullandığını tespit etmekle birlikte, salât gibi bazı kelimelerin anlamlarını zenginleştirdiğini, münâfik ve zekât gibi birtakım kelimelerin anlamlarını dönüştürdüğünü, Allâh ve hac gibi bazı temel dînî kavramların içeriğini yeni baştan düzenlediğini, Kureyş lehçesi dışındaki Arap lehçelerinden ${ }^{101}$ ve hatta diğer dillerden kelimeler aldığı$\mathrm{n1}^{102}$ ve metinsel bütünlüğünü bozmayacak biçimde kendine özgü bir kelime dağarcı̆̆ 1 ve terminoloji kurduğunu da hemen fark eder. Bu kelimeler içerisinde kavramların önemi inkâr edilemez; çünkü İslâm düşüncesinin temelini onlar oluşturmaktadır. İlâhî kelamın anlam inceliklerinin layıkıyla

\footnotetext{
ez-Zerkeşî, el-Burhân, II, 382.

ez-Zerkesî, el-Burhân, II, 383.

ez-Zerkânî, Menâhilü'l-irfân, II, 557.

101 Örnekler için bkz. ez-Zerkeşî, el-Burhân, I, 283-86; es-Suyûtî, el-ìtkân, II, 378 vd.

102 Örnekler için bkz. ez-Zerkeşî, el-Burhân, I, 287-90; es-Suyûtî, el-ìtkân, II, 393 vd.
} 
ortaya konabilmesi için öncelikle bu kavramların sınıflandırılması ve anlamlarının tespit edilmesi gereklidir. Bu amaçla müfessirler ve usulcüler, gerek tefsirlerinde, gerek usule dair genel eserlerinde, gerekse bir veya birkaç usul konusuna tahsis ettikleri araştırmalarında, bu kavramları âmm, hâs, mutlak, mukayyed, hakikat, mecaz, garîb, müşterek, çok anlamlı (vücûh), benzer anlamlı (nezâir) vb. şekillerde sınıflandırarak, ilâhî kelamın anlamsal üstünlüğünü ortaya koymaya gayret etmişlerdir. Diğer bir ifadeyle, ilâhî kelamda izlenen kelime ve kavram seçme tekniği bunu zorunlu kılmıştır.

Üslup, lafız ve mana ile olduğu kadar beyan türü ile de ilgilidir. Bilindiği gibi, konuşmalarda, edebiyatta, bilimsel metinlerde vs. uygulanan birtakım beyan türleri vardır. Nesir, şiir, roman, hikâye/öykü, tavsif, teşrih, istidlal, hitap, makta (kesintili anlatım), sembolizm (rumuzlu anlatım) bunlardan sadece birkaçıdır. Kur'ân'ın anlatım biçimini değinilen kalıplardan herhangi birine dahil etmek mümkün değildir. Bu nedenle Kur'ân'ın edebî üslubunu en iyi tanımlayan kişinin, müşriklerin önemli edebiyatçllarından Velîd b. Mugîre olduğunu söylemek yanlış olmayacaktır. ${ }^{103}$ Nitekim Kureyş müşriklerinin önde gelenleri, Hz. Muhammed'i Mekke'ye gelenlere birbirleriyle çelişmeden söz birliği içerisinde söyleyebilecekleri tek bir sıfatla nitelendirmek üzere toplanmışlar, fakat bir sıfat üzerinde anlaşmaya varamamışlardı. Bunun üzerine Velîd'i, Hz. Peygamber'in anlattıklarını dinleyerek, uygun vasıfla nitelendirmesi için görevlendirmişlerdi. O da görevini tamamladıktan sonra öncelikle onların görüşlerini sormuş, Hz. Peygamber'e "kâhin, deli / cinlenmiş veya sihirbaz" denilmesini önerenlere, durumun hiç de öyle olmadığını söylemişti. "Şair" denilmesini önerenlere ise, "O, bir şair değildir; zira biz şiirin bütün çeşitlerini, recezini, veznini, kısasını, uzununu biliriz." diyerek karşı çıkmıştı. "Öyleyse ne diyelim?" diye soranlara, "Allah'a yemin olsun ki, onun sözünde [Kur'ân'da] bir tatlılık var. Kökü, hurma ağacı [gibi sağlam]. Dalı, olgunlaşmış hurma veya sağanak yağmur [gibi çok fazla]. Oysa sizin bu hususta söyledikleriniz bilinen şeylerdir ki, bunları söylemek boştur. Yine de bu hususta [doğruya] en yakın olan, ona sihirbaz demenizdir; zira o öyle bir söz getirmiştir ki, onunla, kişiyle babasının, kardeşinin, eşinin ve aşiretinin arasını ayırmaktadır. (...)" şeklinde karşılık vermek zorunda kalmıştı. ${ }^{104}$ Söylediklerinin sihre benzememesi sebebiyle Hz. Peygamber'in sihirbaz olamayacağını açıkça itiraf eden Velîd'in bu son sözlerini,

\footnotetext{
${ }^{103}$ Konu hakkında geniş bilgi için bkz. Şeriati, Kur'an'a Bakış, 102-10.

${ }^{104}$ Ebû Muhammed Abdulmelik b. Hişâm el-Himyerî, es-Sîratü’n-nebeviyye, Beyrut: Dâru ihyâi'ttürâsi'l-Arabî, tarihsiz, I, 288-89.
} 
Kur'ân'ın etkileyiciliği karşısındaki şaşkınlığını ele veren ifadeler olarak değerlendirmek daha doğru olacaktır. Çünkü Kureşlilerin verdiği bir görevle Hz. Peygamber'in yanına gelip, ona peygamberlik davasından vazgeçmesini teklif eden Utbe b. Rebîa'nın, onun kendisine okuduğu Fussilet Suresi'nin suresinin nefis üslubu karşısında hayrete düşerek sarfettiği cümlelerinden de anlaşılacağı gibi, Kur'ân'ın hem metni, hem de anlamı gerçekten akıcı, çekici ve büyüleyicidir. Utbe, Kureyşlilerin yanına dönünce, ne haber getirdiğini soranlara, "[Ondan] öyle bir söz duydum ki, Allah'a yemin olsun ki, benzerini daha önce hiç duymadım. Allah'a yemin olsun ki, o ne şiir, ne sihir ve ne de kehanettir. (...) Allah'a yemin olsun ki, duyduğum söz büyük bir mesajdır." cevabını vermiştir. ${ }^{105}$ Son yüzyıllarda yaşayan müsteşrik bilim adamlarından bazıları da Kur'ân'ın filolojik bakımdan mükemmel bir üsluba ve ikna kuvvetine sahip olduğunu, bazı surelerin okunuşunun Arapça bilmeyen Avrupalıları bile duygulandırabildiğini itiraf etmişlerdir. ${ }^{106}$

Kur'ân'ın, kendisine inanmayanları bile duygulandırabilen beyanının özünü, tek bir anlatım türüne bağlı kalmaması, bunun yerine duruma en uygun rengârenk metotları anlatımın akışını ve bütünlügüüü bozmayacak biçimde bir arada kullanması oluşturmaktadır. Onda tarihsel olaylar anlatılır; fakat anlatım tarih kitaplarındaki gibi değildir. Felsefe ve metafizik sorunlar bu konulardaki ders kitaplarından çok farklı bir şekilde ele alınır. İnsandan ve evrenden, tabiat bilimlerindekinden farklı bir dille bahsedilir. Aynı şekilde kültürel, politik, sosyal ve ekonomik problemleri çözmede kendi metodunu izler; kanunları ve prensipleri sosyologlardan, hukukçulardan ve hakimlerden farklı bir şekilde ele alır. Ahlâk, bu konuda yazılan bütün eserlerden farklı bir yolla öğretilir. ${ }^{107}$ Kısaca onda, muhatapların ruhlarına nüfuz etmek amacıyla şiirimsi, nizam vermek amacıyla hukukumsu-ahlakımsı, ögüt vermek amacıyla hikayemsi-vaazımsı, geçmiş olaylardan ibret alınmasını sağlamak amacıyla romanımsı vs. bir üslup kullanılmıştır. Bunun yanı sıra bazen de Allah'ın varlığını ispat etmek maksadıyla istidlâlî, insanların ahiretteki durumlarını anlatmak maksadıyla tasvîrî veya tavsîfî bir anlatım tercih edilmiştir. Zaman zaman iç âhengi sağlamak amacıyla seci yoluna başvurulmuş, ayetlerin fâsılaları ses uyumları ve ritimlerle süslenmiştir. Bazen tek bir bölümde bile, lügavî güzelliklerle edebî sanatlar da işe katılarak, kelimelerin ve cümlelerin öyle bir armonisi gerçekleştirilmiştir

105 İbn Hişâm, es-Sîra, I, 314.

106 Cerrahoğlu, Tefsir Usulü, 161.

107 Ebu'l A'lâ Mevdûdî, Tefhimu'l Kur'ân Kur'an'ın Anlamı ve Tefsiri, çev. M. Han Kayanî vd., 2. baskı, İstanbul: İnsan Yay., 1991, I, 16. 
ki, -inansın veya inanmasın- okuyan ya da işiten kişilerin ekserisi onun büyüleyiciliğinden kendisini kurtaramamıştır. Zira onun kelime, kavram ve deyimleri hem konuyla, hem de birbiriyle uyumlu, terkibi mükemmel, cümleleri akıc1, ifadeleri duygulu ve vurgulu, meselleri parlak, benzetmeleri çarpıcı, sözleri yerli yerinde ve nezaketli, mantık kurgusu üstün, delilleri güçlü (fakat bilimsel ifadelerden ziyade sözlü anlatım özelliklerinin hakim olduğu bir metin), yeminleri yapmacıksız ve ikna edici, dünya ile ilgili kural ve önerileri makuldür; tilâvetinin musikisi son derece hoştur. Hangi yönden ele alınırsa alınsın, o, insanların hem maddelerine, hem de ruhlarına hitabeden yeterli bir şâheserdir.

Türü ne olursa olsun, Kur'ânî anlatımın hemen her kademesinde insanların Allah'a karşı sorumlu oldukları belirtilmiş, bu sorumluluğu yerine getirebilmeleri için onlara eylem (amel) modelleri sunulmuş, iyi ve kötü eylemlerin dünyevi ve uhrevi sonuçları gösterilmiş, insanların bu dünyada sergiledikleri davranışların ve yaptıkları işlerin karşılığını ahirette görecekleri vurgulanmıştır. Hitap, başta Müslümanlar olmak üzere bütün insanlara yöneltilmiştir. Amaç, onları ikna ederek, doğru yola ulaşmalarını, hidayete kavuşmalarını ve kurtuluşa ermelerini sağlamaktır. Bu amaç, Kur'ân'ın temel yapısının, her yerde hâzır ve nâzır, yüce Kelâm Sahibi'nin alıcının bilincini kökten değiştirmek için açıkça müdahale ettiği bir diyalog olması sonucunu doğurmaktadır. ${ }^{108}$ Sorulan bir soruyu tekrarla, yeni bir soruyla, soyut harflerle (el-hurûfu'l-mukattaa), mukayeselerle (Yaratan Allah mı, putlar mı?), iddialarla, yeminlerle, ikili anlatım (doğru-yanlış, iyi-kötü, Cennet-Cehennem, mükâfât-ceza) yöntemiyle, uyarılarla, hayret ifadeleriyle, benzetme, örnek, simge ve mesellerle ve daha pek çok dilsel enstrümanla, biraz da sohbet havasını andıran bir anlatımla muhatap ikna edilmeye çalışılmaktadır. Bu bağlamda, gerekli görüldügünde sembolik / simgesel anlatım yoluna da başvurulmaktadır. ${ }^{109}$ Zira sözün etkisini artırma, dikkatleri somut olanın arkasındaki manevi öze yöneltme, soyut olanı somut olanla gösterme, ${ }^{110}$ bir kelimeye ince ve/veya yeni bir anlam yükleme, bilimsel düzeyin yetersiz kalmasından dolayı hakikatin inkâr edilmesini önleme (zira sembo-

\footnotetext{
${ }^{108}$ Muhammed Arkoun, Kur'ân Okumaları, çev. A. Zeki Ünal, İstanbul: İnsan Yay., 1995, s. 122-23.

109 Arkoun, Kur'ân Okumaları, 93-94.

Kur'ân'daki sembolik anlatımlar, İslâm'ın temel prensiplerine uygun olarak anlamlandırllır. Meselâ, Allah'a "kral" (melik) denilmesi, "Onun göklerdeki ve yerdeki her şeyin sahibi olması" şeklinde tevil edilir. Bu ve diğer örnekler için bkz. Muhammed Hamidullah, İslâm'da Sembolik Anlatım, çev. Sadık Kılıç, “İslâm'da Sembolik Dil (ss. 217-31)”, haz. Sadık Kılıç, İstanbul: İnsan Yay., 1995, s. 219 vd.

110 Sadık Kılıç, İslâm'da Sembolik Dil, 49-50.
} 
lik anlatımdan herkes ilmî seviyesine göre bir anlam çıkaracaktır) gibi nedenler, sembolik anlatımı gerekli kılmaktadır. ${ }^{111}$ Sembolik anlatım, Kur'ân'in kelimeleri, kavramları, ayet ve sureleri arasındaki gizli ve/veya şifreli ilişkilerin ortaya çıkarılması gibi bir anlam da taşımaktadır. ${ }^{112}$

Üslupla ilgili olarak üzerinde durulması gereken diğer bir husus, Kur'ân'in konusal bütünlüğü meselesidir. Bilindiği gibi, bir yazar eserini belli bir konu sıralamasına göre yazar; değerlendirmeleri, o konuyla ilgili bilgi, fikir ve tartışmaları aşmaz; hitabın yönü ve biçimi kolay kolay değişmez. Oysa Kur'ân, konularına göre tertip edilmiş değildir; aynı konuyla ilgili ayetler onun farklı sureleri içerisinde yer alabilmektedir. Hatta bir ayetle konulan geçici bir hüküm, sonradan gelip, farklı bir sureye yerleştirilen bir ayetle neshedilebilmekte, aşamalı metotla (tedrîc) yerleştirilen bir hükmün dayandığı ayetler farklı surelerde yer alabilmektedir. Bu arada konuşmacı, hitaplar ve hitabın yönü de sürekli değişmekte, hiçbir yerde konuları ayıran herhangi bir işaret bulunmamaktadır. ${ }^{113}$ Bu anlatılanlara bakarak, Kur'ân'da konu bütünlüğü bulunmadığı gibi bir zehaba kapılmamalıdır; onun kendine has bir konu bütünlüğü vardır. Dünya nimetlerinden bahsedilirken birden ahirete, oradaki mükâfât veya cezaya değinilmesi, konunun koparılışından veya değiştirilişinden değil, insanların bu nimetleri kullanmakla ilgili davranışlarının karşılıksız kalmayacağını hatırlatma isteğinden kaynaklanmaktadır. O halde bu anlatım biçimini konu bütünlügünden uzak görmek yanlıştır. Bununla birlikte her ayeti veya ayet grubu değişik vesilelerle farklı zamanlarda inmiş 10-20 sayfadan müteşekkil bir surenin aynı konudan bahsettiğini ileri sürmek de gerçeklerle bağdaşmamaktadır. Ancak Kur'ân'ı okuyan herkes görür ki, anlatımın akıcılığı bozulmadan bir konudan diğerine geçilebilmektedir. Ĕger dikkatli davranmazsa, okuyucu kendini bu akıcılı̆̆a kaptırarak, konunun değiştiğini hiç farketmeden uzun bir sureyi bitirebilir. Yani Kur'ân, metni uzun olmasına ve bir konuyla ilgili amaçları çeşitlilik arzetmesine rağmen, gerek bütün parçalarının birbirine bağlı olması, gerekse kelimelerinin, cümlelerinin, ayetlerinin ve surelerinin birbirine kenetlenmesi yönünden öyle bir noktaya ulaşmıştır ki, başka hiçbir kelâm bu hususta onunla boy ölçüşemez. ${ }^{114}$ Önemli olan, bir ayet açılklanırken, o ayetle ilgili diğer ayetlerin tamamını, hatta hadisleri ve sahabi görüşlerini göz önünde bulundurmak suretiyle, parçacı yaklaşımların terk edilmesi ve bütünlü-

\footnotetext{
111 Şeriati, Kur'an'a Bakış, 104-06.

112 Şeriati, Kur'an'a Bakış, 111.

113 Mevdûdî, Tefhimu'l Kur'ân, I, 16.

114 ez-Zerkânî, Menâhilü'l-irfân, II, 561-62.
} 
ğün sağlanmasıdır. ${ }^{115} \mathrm{O}$ halde, son zamanlarda, Kur'ân'ın sırasıyla değil, konularına ayrılarak tefsir edilmesi talebiyle ortaya çıkan ${ }^{116}$ konulu tefsir hareketini, en azından hedefleri açısından haklı görmek zorunludur.

Kur'ân'ın üslubuyla ilgili olarak, olağanüstü güzellikteki yeminlere, zaman zaman görülebilen tekrarlara ve sinırlı anlatımlara da temas etmemiz zorunlu görünmektedir. Yeminlere yukarıda yeteri kadar temas ettik, aynı konuya dönmeyi gereksiz buluyoruz. Tekrarlar ise, ilâhî kelamdaki anlatım üslubunun bir gerçeğidir. Fakat unutulmamalıdır ki, onun bıktırıcı fazlalıkta olmayan tekrarları, sırf tekrar olsun diye amaçsızca yapılmış değil, çoğunlukla yeni mesajlar çağrıştırıcı niteliktedir. 'Öyleyse, Rabbinizin hangi nimetlerini yalanlıyorsunuz?' ayetinin, Allah'ın, Kur'ân'ı bildirdiğini, insanı yarattığını, ona beyanı öğrettiğini, kâinat için bir nizam koyduğunu, dünyayı canlılar için tahsis ettiğini, orada türlü türlü maddi nimetler var ettiğini belirten ayetlerden sonra gelmesi ile, hem Allah'ın, insanları kuru balçıtan, cinleri de ateş alevinden yarattığını haber veren ifadelerden, hem de iki doğunun ve iki batının Rabbi olduğunu hatırlatan ilâhî sözden ${ }^{117}$ sonra tekrarlanması arasında verilmek istenen mesaj bakımından az da olsa bir fark bulunmadığını kim iddia edebilir? Bu ayetin, ilk ayet grubundan sonra genel nimetler, ikinci ayetlerden sonra hayat verme nimeti hatırlatılıp, bunları yaratan Allah'a şükretmek gerektiğine daha fazla vurgu yapılırken, üçüncü ayetten sonra ise, varlığı devam ettirdiği (Rab) için Ona yönelmek gerektiği mesajı daha çok hissettirilmektedir. Öte yandan tekrarlarda musiki güzelliğinin de ön planda tutulduğu, böylece bıktırıcılığın maharetle önlendiği de anlaşılmaktadır. Nitekim, yazarı ne kadar becerikli olursa olsun, insan telifi olan eserlerde görülen tekrarlar hemen dikkat çektiği ve okuyucunun kulaklarını tırmaladığı halde, Kur'ân'da tekrarlar metin içerisine öyle maharetle yerleştirilmiştir ki, bunlar ne okuyucuyu bıktırmakta, ne dinleyiciyi rahatsız etmekte; tam aksine ikisine de haz vermektedir.

Sınırlı anlatıma gelince, Yûsuf kıssası örneğinde olduğu gibi -ki, yaklaşık 12 sayfalık Yûsuf Suresi bu kıssa ile ilgilidir-, Kur'ân'da olaylar bazen ayrıntılı bir biçimde tasvir edilse bile, İsrail oğullarının Hz. Musa ile Mısır'dan çıkmalarına izin vermeyen Firavun ve taraftarlarının üzerlerine tufan, çekirge, haşere, kurbağa ve kan gönderilmesi mucizelerinde olduğu gibi, ${ }^{118}$

115 Ebü'l-Fidâ' İsmail İmâdüddin b. Ömer b. Kesîr, Tefsîru'l-Kur'âni'l-Azîm, thk. M. İbrahim el-Bennâ vd., Kahire: Dâru'ş-Şa'b, tarihsiz, I, 12-13; Halis Albayrak, Kur'ân'ın Bütünlüğü Üzerine -Kur'ân'ın Kur'ân'la Tefsiri-, İstanbul: Şûle Yayınları, 1992, s. 43 vd.

116 Halis Albayrak, Tefsir Usûlü Yöntem - Ana Konular - İlkeler - Teklifler, İstanbul: Şule Yayınları, 1998, s. 117-18.

117 Rahmân (55), 1-18.

118 A'râf (7), 133-134. 
zaman zaman olaylar kısaca anlatılmakta veya yalnızca ismen atıf yapılmaktadır. Birçok kıssada anlatım yalnızca ibret alınmasını sağlayacak miktarla sinırlı tutulmakta, fakat olayın yeri, tarihi, kahramanları vb. ayrıntılar verilmemektedir. İlave olarak, vahiy dönemindeki Arap dilinin imkanlarını zorlayarak, insanın asılı bir nesneden veya [pıhtılaşmış] kandan (alak) yaratıldığını / üretildiğini belirten ayette ${ }^{119}$ olduğu gibi, kavram yalnızca dînî bilgilerle anlaşılamayabilmektedir. Metin sunumunun ilâhî mesajı ve amacını gerçekleştirecek kadarla sınırlı kalabilmesi, bu nedenlerle ilk bakışta bir dezavantaj imiş gibi görünse de, aslında Kur'ân ve onun tefsiriyle gerek kendinden önceki kutsal kitapları, gerekse diğer bilim dallarını buluşturan bir düzlem oluşturması bakımından önemli bir avantaj olarak da değerlendirilebilir. Sözgelimi, Anlatımdaki sınırlılığın getirdiği zorlukların aşılabilmesi için, İslâm'ın ilk asırlarından itibaren ehl-i kitabın kutsal kitaplarından özellikle kıssaların ayrıntılarının belirlenmesi hususunda- ihtiyatlı bir şekilde yararlanma yoluna başvurulmaktadır. ${ }^{120}$ Tıp biliminin yardımıyla, insanın yaratıldığı asılı nesneye veya pıhtılaşmış kana artık "döllenmiş yumurta" (embriyo) anlamı verilmektedir. ${ }^{121}$ Kısacası, yukarıda bahsi geçen türden ayetlerin daha iyi anlaşılması için tıp, edebiyat, tarih, hukuk, iktisat, felsefe, dilbilim, psikoloji, sosyoloji, antropoloji, astronomi gibi bilim dallarından yararlanılmaktadır. Bu arada, bazı ayetlerdeki anlatım sınırlılığı, indikleri ortam veya inişlerine vesile olan olay (nüzul sebebi) ile doğrudan ilişkilidir; bunların doğru anlaşılabilmesi, ancak ilgili oldukları ortam veya olayın doğru tespiti ile mümkün olabilmektedir. İman edip, salih amel işleyenlere tattıklarından dolayı hiçbir günah yoktur." ${ }^{\text {"22 }}$ ayeti böyledir. İlk bakışta bu ayet şarabın meşru olduğunu akla getirse de, aslında şarap haram kılınmadan önce ölen sahabilerin Allah katında sorumlu olmadıklarını belirtme amacı taşımaktadır. ${ }^{123}$

Öte yandan birçok ayette, bir peygamberden, veliden (Allah dostu) veya başka bir insandan, melekten, cinden, hayvandan, yerden, binadan, ağaçtan veya yıldızdan bahsedildiği halde, bunların kim, ne veya neresi olduğu hakkında açık bilgi verilmemekte, özel isimleri (alem) zikredilmemektedir. Bunun yerine "âmâ, Allah'ın nimet verdikleri, mescit" örneklerinde olduğu

119 Alak (96), 2.

${ }^{120}$ Cerrahoğlu, Tefsir Usulü, 245-46; Abdullah Aydemir, Tefsirde İsrâiliyyât (Hicrî 6. Asrın Bașına Kadar), Ankara: DïB Yay., 1971, s. 43 vd. İdris Şengül'ün Kur'ân Kıssaları Üzerine (İzmir, 1994) isimli araştırması, Kur’ân kıssalarını bizim yukarıda değindiğimiz husus da dahil olmak üzere çeşitli yönlerden ele alan geniş ve doyurucu bir çalışmadır.

${ }^{121}$ Muhammed Esed, Kur'ân Mesajı, 1287.

${ }^{122}$ Mâide (4), 93.

123 et-Taberî, Câmiu'l-beyân, VII, 36-38; Cerrahoğlu, Tefsir Usulü, 117. 
gibi cins isimlerle, hatta sadece ism-i mevsullerle veya zamirlerle atıf yapılarak yetinilmektedir. Usulcülerin "müphem" adını verdikleri bu tür ifadelerin anlaşılması, onlarla ilgili olarak Hz. Peygamber ile sahabilerinden gelen haberlerin, hem tarihsel, hem de metinsel bağlamlarının (nüzul sebepleri, siyâk, münâsebât) bilinmesine bağlıdır. ${ }^{124} \mathrm{Bu}$ arada yeri gelmişken belirtmeliyiz ki, münâsebet konusu yalnızca sınırlı / özet anlatımla ilgili değildir. Ayetlerin ve surelerin peş peşe getirilişinde görülen mükemmel güzellik ve âhenk bu konunun kapsamına girdiği gibi, aynı meseleyle ilgili olan ayetlerin değişik surelerde bulunmasına karşın meydana getirdiği konusal bütünlük, ilk ayetinden son ayetine kadar bütün Kur'ân ifadelerinin birbiriyle oluşturduğu metinsel ve anlamsal düzenlilik ve ilâhî metnin her bir parçasının mesaj, amaç, ses düzeni, anlatım tarzı vb. açılardan oluşturduğu uyumluluk da bu konu içerisinde ele alınmaktadır. ${ }^{125}$ Bunlardan ötürü bazen bu konu "Tenâsüb ve İnsicâm" başlı̆̆ 1 altında işlenmektedir. ${ }^{126}$

Son bir üslup özelliği olarak, ilâhî kitabın önemli bir kısmının, geniş bir anlam yelpazesi içerisinde değişik yorumlara imkan tanımasını zikredebiliriz. Gerçekten, onun manalarına, öyle bir lafız kalıbı giydirilmiştir ki, bu özelliği ona, aynı veya değişik zamanlarda, aynı veya ayrı diyarlarda yaşayan ve ilmi seviyeleri farklı olan bütün insanlara hitap edebilme nimeti bahşetmiştir. ${ }^{127} \mathrm{Bu}$ hitaba muhatap olan herkes onda kendisiyle ilgili bir şeyler bulmakta, onu, aklının, bilgi düzeyinin, kültürünün, sosyal konumunun vs. elverdiği ölçüde kavramaktadır. Onu anlamak, kişilerin donanımlarıyla olduğu kadar, insanoğlunun yaptığı yeni keşiflerle ve ulaştığ genel bilimsel düzeyle de ilgilidir. Kur'ân metninin bir kısmında, ortaya çıan yeni durum ve bilimsel gelişmelere göre yeni yorumlara imkan verebilecek, tabiri caizse, güncellenebilecek esnek bir anlatım üslubu tercih edilmiştir. 'Güneş, kendine ayrılan yeri dolaşır. (...) Ay için birtakım evreler takdir ettik." ${ }^{128}$ ayetlerinden günümüz müfessirlerinin çıkartacağı anlam, İslâm'ın ilk asırlarında yaşayan müfessirlerin çıkarttığı anlama nispetle çok daha geniş olmalıdır.

\footnotetext{
${ }^{124}$ Kur'ân'ın müphemleri hakkında geniş bilgi için bkz. Abdurrahmân es-Süheylî, Kitâbü't-ta'rîf ve'la'lâm fîmâ übhime fi'l-Kur'ân mine'l-esmâi'l-a'lâm, thk. Abdullah Muhammed Ali en-Nakrât, Trablus: Menşûrâtü Külliyyeti'd-da'veti'l-İslâmiyye, 1401/1992, s. 50 vd.; ez-Zerkeşî, el-Burhân, I, 155-63; es-Suyûtî, el-ïtkân, IV, 382 vd.; Cerrahoğlu, Tefsir Usulü, 186-88.

125 Ayrıntılar için bkz. ez-Zerkeșî, el-Burhân, I, 35 vd.; Celâleddîn Abdurrahman b. Ebî Bekir esSuyûtî, Tenâsüku'd-dürer fì tenâsübi's-süver, thk. Abdulkâdir Ahmed Atâ, Beyrut: Dâru'l-kütübi'lilmiyye, 1406/1986, 53 vd.; Cerrahoğlu, Tefsir Usulü, 204-07.

${ }^{126}$ Cerrahoğlu, Tefsir Usulü, 204.

127 Yıldırım, Kur'ân İlimlerine Giriş, 141-42.

128 Yâsîn (36), 38-39.
} 
Böylesi ayetler özellikle geçtiğimiz yüzyıl içerisinde yoğun bir ilgiyle karş1laşmış, neticede "ilmî tefsir" adında yeni bir tefsir türü doğmuştur. Şâtıbî'den (790/1388) itibaren birçok ilim adamı, "Kur'ân'ın kapsamadığı bir şeyi ona izafe etmek caiz değildir." temel prensibiyle tefsirin bu türünü sakıncalı bulmuşlarsa da, onların itirazlarının asıl amacının, ayetlere zorlama anlamlar veren ve Kur'ân'ı müspet bilimlere uyarlamaya yönelen aşırılıkları önlemek olduğu anlaşılmaktadır. Dolayısıyla, İslâm'ın temel esaslarıyla çelişmemek, aşırıya kaçmamak ve tefsirin amacını aşmamak şartıyla bu tür tefsirin müfessirler arasında genel olarak kabul edildiği söylenebilir. ${ }^{129}$

Buraya kadar verdiğimiz bilgilerden açıkça anlaşılmaktadır ki, Kur'ân kendine özgü bir üsluba sahiptir. Arap toplumunun İslâm'dan hemen önceyi ve sonrayı kapsayan döneminde böyle bir anlatım stilinin olmaması, hatta bu stilinin, gerek aracisı olan Hz. Muhammed'in hadislerinin, ${ }^{130}$ gerekse vahiy sürecinin önceki kitaplarının üslubuna benzememesi, ${ }^{131}$ vahiy sürecinde tarihsel öğelerin -en azından anlatım tarzının başat özellikleri bakımından- nasıl aşıldığını, nasıl yeni bir beyan şekli geliştirildiğini açıkça gözler önüne sermektedir. Bu beyan şekli içerisinde, kişiler ve toplumlar için hayat düsturları gösterilmekte, hidayete ve kurtuluşa ulaştırıcı öğütler yapılmakta, hem geçmişe ait, hem de gelecekten haberler verilmekte, kıssalar anlatılmakta, aynı ayette bile -amaca hizmet edecek tarzda- konudan konuya geçilebilmektedir; bunlar gönüllere hoş gelecek, inanmayanları bile etkileyecek sanat harikası bir söz-metin-anlam bütünlüğü içerisinde gerçekleştirilmektedir. Oldukça uzun tahlil ve tefsir gerektiren bu kadar zengin bir içeriğin, aynı fotoğraf karesi içerisinde yer alan şekil ve renklerin oluşturduğu bütünlük gibi, hiçbir ifade zafiyeti göstermeksizin aynı ayet grubu içerisinde yoğrulması, Kur'ân'ın üslubunun yüceliğine ve ilahi kaynaklı olduğuna tanıklık etmektedir. Yüzyıllar boyunca hiçbir edebiyatçı, söz ve kalem ustasının onun bir benzerini ortaya koyamamış olması, bu gerçeği perçinlemektedir. Zira bizzat Kur'ân, kendi benzerini yapmaları hususunda -inanan

129 Konuyla ilgili geniş bilgi ve tartışmalar için bkz. Ignaz Goldziher, İslâm Tefsir Ekolleri, çeviren ve notlandıran: Mustafa İslamoğlu, İstanbul: Denge Yay., 1997, s. 374-82; Cerrahoğlu, Tefsir Usulü, 303-09; ; Keskioğlu, Kur'ân-ı Kerim Bilgileri, 263 vd.; Celâl Kırca, Kur'ân-ı Kerîm ve Modern İlimler (Münâsebeti-Yorumu-Yorumcuları), 2. bask1, İstanbul: Marifet Yay., 1982, s. 51 vd.; Y1ld1rım, Kur'ân İlimlerine Giriş, 202 vd.; Salih Akdemir, İlmî Tefsir Hareketinin Değerlendirilmesi ve On Dokuz Rakamı Üzerine, "Kur'ân'ın Anlaşılmasına Doğru (ss. X-XLVIII)”, çev. S. Akdemir, Ankara: Mim Yay., 1983, s. XI vd.; Said Şimşek, Günümüz Tefsir Problemleri, Konya: Esra Yay., 1995, s. 79 vd.; Zarzûr, Ulûmu'l-Kur'ân, 33 vd.

130 ez-Zerkânî, Menâhilü'l-irfân, II, 578-79.

131 Cerrahoğlu, Tefsir Usulü, 159. 
veya inanmayan- bütün insanlara ve cinlere -kolektif çalışmalarına da izin vererek- meydan okuduktan sonra, ilâhî kaynaklı olduğuna dikkat çekmektedir: 'Şayet insanlar ve cinler bu Kur'ân'tn benzerini ortaya koymak üzere bir araya toplansalar, birbirlerine destek de olsalar, yine onun benzerini ortaya koyamazlar. ${ }^{132}$ Kur'ân üzerinde hâlâ iyice düşünmeyecekler mi? Eğer o, Allah'tan başkasindan gelseydi, onda birçok tutarsızlık bulurlardı. ${ }^{133}$ Bu meydan okumalar, onun kadar açık, akıcı ve çekici, onun kadar kısa, çelişkisiz, tutarlı ve anlam yüklü bir metin üretme ile ilgili olsa gerektir.

Metodolojik açıdan Kur'ân'ın üslubu, tefsir ilimleri adı verilen konuların hemen hepsi ile ilgili görünmektedir. Daha doğrusu, bu usul konularının ortaya çıkışında en büyük etken, Kur'ân'ın yukarıda ana hatlarını çizmeye çalıştığımız üslubudur. Farklı bir ifadeyle, ilâhî hitaptaki anlatım biçimi, onun fesâhat ve belâgat özelliklerinin, bütün çeşitleriyle kavramlarının, ayetleri arasındaki irtibat, tenâsüp ve insicamın, ayetlerinin siyâkının, tedrîcî inişinin, nüzul sebeplerinin, nâsihinin, mensuhunun, müşkillerinin vs. ele alınmasını zorunlu kılmıştır. Usulcülerin, ya müstakil başlıklar halinde etraflıca inceledikleri, ya da diğer usul konuları içerisinde değindikleri bu konular Kur'ân'ın tefsirini de doğrudan etkileyerek şekillendirmiştir. Zira bir müfessirin tefsirine -kaçınılmaz olarak- onun bu temel konularla ilgili görüşleri damgasını vurmaktadır. Öte yandan bu üslup, bir yandan Kur'ân'ın asırlar boyunca sürekli olarak yeniden yorumlanmasını gerekli kılarak, çok sayıda tefsir kitabının ortaya çıkmasına yol açarken, diğer yandan "tefsir diye bir bilim dalı olmadığını" iddia eden bazı çağdaş bilim adamlarının ${ }^{134}$ görüşlerinin temelden yoksun olduğunu da gözler önüne sermektedir.

\section{Kur'ân'ın Şekilsel Özellikleri}

Klasik Kur'ân anlayışının birinci hareket noktasını ilâhî kitabın öznitelikleri teşkil ediyorsa, ikinci hareket noktasını da şekilsel özellikleri oluşturmakta-

\footnotetext{
132 İsrâ (17), 88.

133 Nisâ (4), 82.

${ }^{134}$ Kur'ân'da, hukuk, tarih, iktisat, kelâm, dilbilim, edebiyat gibi birçok bilim dalını ilgilendiren çok yönlü ve çok özellikli ayetler veya ayet grupları varken, bu ayetlerin -bu bilim dallarından da istifade edilerek- belli bir bütünlük içerisinde açıklanması zorunlu iken, üstelik karşımızda ilâhî kelâmın üslubundan kaynaklanan bunca usul konusu dururken, bazı değerli meslektaşlarımızın "tefsir diye bir bilim dalı olamayacağını" söylemeleri gerçekten tuhaftır. Bilimsel kariyerini tefsir biliminde sürdüren bir meslektaşımızın, nereden icap ettiyse, bu görüşü yazılı olarak dile getirmesi ise, hem gerçeklere ters düşmesi, hem de bütün Kur'ân ve tefsir araştırmacılarını "boş işlerle uğraşan kişiler" konumuna düşürmesi sebebiyle son derece suçlayıcı, bir o kadar da üzücüdür. Belirtilen görüş için bkz. Mustafa Öztürk, Tefsirde Usûl(süzlük) Sorunu, İslâmiyât Üç Aylık Araştırma Dergisi, C. VI, sayı: 4, Ekim-Aralık 2003 (ss. 69-84), s. 83.
} 
dır. Biz bu araştırmamızda "şekilsel özellikler" tamlamasıyla, Kur'ân'a tertibi ve resmi itibariyle atfedilen nitelikleri kastediyoruz. Bu iki hususla, yani Kur'ân'ın tertibi ve resmi ile ilgili olarak oluşan kültürel miras, klasik Kur'ân tasavvurunun önemli köşe taşlarındandır. İlaveten bu iki husus, geleneksel tefsirin ve usulünün hem oluşumunda, hem de gelişiminde -Kur'ân'ın öznitelikleri kadar olmasa bile- önemli bir paya sahiptir. Konuya girmeden önce burada kullandığımız tertip ve resim terimlerine açıllık getirmemiz yerinde olacaktır. Usulcüler, Kur'ân'ın tertibi (tertîbü'l-Kur'ân) terimiyle, hem ayetlerin sureler içindeki dizilişlerini, hem de surelerin Kur'ân içindeki sıralanışlarını kastetmektedirler. ${ }^{135}$ Kur'ân'ın / Mushaf'in resmi (resmü'l-Kur'ân / Mushaf, er-resmü'l-Osmânî) terimi ise, ilâhî kelamın kelime ve harflerinin üçüncü halife Osman b. Affân'ın (35/656) oluşturduğu ilmî heyet ${ }^{136}$-ki, üyelerinin kimliklerinin ve karakterlerinin ayrıntılı tespiti, bu kişilerin tercih edilmelerinin sebeplerini belirleme açısından heyecan verici müstakil bir araştırmaya konu yapılabilir- tarafından yazılan şekli anlamında kullanılmaktadır. ${ }^{137}$ Tefsir usulü terminolojisinde, "Kur'ân ayetlerinin ve surelerinin yazma veya ezber yoluyla tespiti, bunların Hz. Peygamber döneminde kısmen, Ebû Bekir (13/634) ve Osman (35/656) dönemlerinde de tamamen bir araya toplanarak Mushaf haline getirilmesi" anlamında kullanılan "Kur'ân'ın toplanması / birleştirilmesi" (cem'u'l-Kur'ân) kelimesi, ${ }^{138}$ bu iki terimin de anlamını kapsamaktadır. Usulcüler tarafından yapılan tanımlarını zikrettiğimiz bu üç terimin anlamlarının bu kadar iç içe girdirilmesinin teknik açıdan ne kadar doğru olduğu tartışılabilir; ne var ki, bunu tartışmanın yeri burası değildir.

a. Tertibi

Bilindiği gibi, bir sure içerisinde başlangıç (ra's, mebde', matla') ve bitiş noktası (makta') bulunan Kur'ân ifadelerine ayet adı verilmektedir. Genel kabule göre, bir Kur'ân ifadesinin tam bir ayet olup olmadığı, akılla veya

135 ez-Zerkânî, Menâhilü'l-irfân, I, 244, 247; Subhî es-Sâlih, Mebâhis fî ulûmi'l-Kur'ân, 65 (Türkçe'si için bkz. Kur'ân İlimleri, 55); Cerrahoğlu, Tefsir Usulü, 86.

136 Hz. Osman'ın olușturduğu bu komisyonda görev alan, fakat hem isimleri, hem de saylları rivayetten rivayete değişiklik gösteren kişilerle, onların kimlikleri hakkında kısa bilgiler ve değerlendirmeler için bkz. Hayrettin Öztürk, Ebedî Mucize Kur'ân Yazılması ve Toplanması, 3. baskı, İstanbul: Ensar Neşriyat, 2005, s. 126-132.

137 ez-Zerkânî, Menâhilü'l-irfân, I, 259-60.

138 ez-Zerkeşî, el-Burhân, I, 237, 241, 258-59; es-Suyûtî, el-i̇tkân, I, 160, 164, 171; Subhî es-Sâlih, Mebâhis fì ulûmi'l-Kur'ân, 65, 69 (Türkçe'si için bkz. Kur'ân İlimleri, 55, 58); Cerrahoğlu, Tefsir Usulü, 66-69; Mennâu'l-Kattân, Mebâhis fì ulûmi'l-Kur'ân, et-tab'atü's-sâlise ve'l-işrûn, Beyrut: Müessesetü'r-risâle, 1411/1990, s. 118-19. 
kıyasla değil, Allah ve/veya Peygamberinin (eş-Şâri') bildirmesiyle (tevkîfí) ve duyma yoluyla (semâî) anlaşılır; çünkü ayetleri tayin etmenin bunun dışında herhangi bir ölçüsü yoktur. ${ }^{139}$ Yine bu yüzden Yâ-sîn ${ }^{140}$ örneğinde olduğu gibi, bazen yalnızca iki veya daha fazla harften müteşekkil bir ifade tam bir ayet olabilirken, bazen de bir cümle veya borçlaşma ayeti ${ }^{141}$ örneğinde olduğu gibi, uzunca bir vahiy kesiti bir ayet sayılabilmektedir. Bununla birlikte, sure başlarındaki besmelelerin müstakil bir ayet olup olmadığının bilinememesi, Hz. Peygamber'in durduğu ayet sonlarının tam olarak tespit edilememesi, Fâtiha Suresi'nin son ayeti gibi bazı ayetlerin iki ayet sayılabilmesi gibi sebepler, Kur'ân'daki ayet sayısı üzerinde tam bir görüş birliğine ulaşılmasını engellemektedir. ${ }^{142}$ Ancak bu, Kur'ân'ın günümüzdeki Mushaflarda da kayıtlı bulunan metniyle ilgili bir ihtilaf olmayıp, yalnızca ayetlerin numaralandırılması ile ilgili küçük bir görüş ayrılığından ibarettir.

Kur'ân ayetlerinin iniş sırasına göre tertip edilmediği, farklı bir anlatımla, kronolojik sıralama ile telif ve tilavet sıralamasının farklı olduğu bilinen bir gerçektir. Telif tekniği açısından değerlendirilecek olursa, ilk bakışta normalin dışında görülebilecek bu durum, vahiy süreci içerisinde ilâhî iradenin hedef toplumu sürekli murakabe altında tutmasıyla ve seçtiği olaylarla bağlantılı bir şekilde Hz. Peygamber'le iletişim kurarak yeni ayetler göndermesiyle açıllanabilir. Peygamber'in, çeşitli vesilelerle inen bu yeni ayetleri, konularına, getirdikleri mesajlara, amaçlarına vs. en uygun surelere yerleştirmesi, gayet doğal karşılanmalıdır. Esasında bu, Kur'ân'ın Allah tarafından vahyedildiğini gösteren önemli bir mucize olarak değerlendirilmelidir; çünkü kısa sureleri saymazsak, yüz civarındaki kompozisyonun bir defada tamamlanmayarak, yıllar alan bir zaman süreci içerisinde meydana gelen birtakım olaylar vesilesiyle veya hiçbir vesile olmaksızın kurulan cümlelerin, gayet mâhirâne bir şekilde telif edilmesi, Peygamber bile olsa, okuma-yazma bilmeyen bir kişinin gücünü aşan bir durumdur. Şu halde bu, telif açsından da muhteşem bir olay olarak görülmelidir.

Usul bilginleri, ayetlerin Hz. Ebû Bekir ve Osman dönemlerinde yapılan sıralamasının bugün Mushaf ta kayıtlı bulunan şekliyle tevkîfî olduğu, yani

139 ez-Zerkeşî, el-Burhân, I, 266; ez-Zerkânî, Menâhilü'l-irfân, I, 239-41; Cerrahoğlu, Tefsir Usulü, 55; Yıldırım, Kur'ân İlimlerine Giriş, 41-43; Mennâu'l-Kattân, Mebâhis fî ulûmi'l-Kur'ân, 139.

140 Yâsîn (36), 1.

141 Bakara (2), 282.

${ }^{142}$ Mukaddimetü Kitâbi'l-mebânî, müellifi belli değil, thk. Arthur Jeffery, "Mukaddimetân fî ulûmi'l-Kur'ân (ss. 5-250)", Kâhire: Mektebetü'l-hâncî, 1954, s. 246-48; ez-Zerkeşî, el-Burhân, I, 251-52, 267-68; ez-Zerkânî, Menâhilü'l-irfân, I, 180-89, 242-43. 
bu sıralamanın Hz. Peygamber'in Yüce Allah'tan aldığı gibi korunduğu, dolayısıyla bu konuda fikir yürütme ve içtihada yer bulunmadığ 1 hususunda görüş birliği içerisindedirler. Hatta onlar, ümmetin bu hususta tam bir görüş birliği içerisinde olduğunu (icmâ-i ümmet) ifade ederek, görüşlerini nakli ve akli birçok delile dayandırmaktadırlar. Bunların en önemlilerini şöyle sıralayabiliriz: Hz. Rasülüllah kendisine vahyedilen ayetlerin hangi surenin neresine yazılacağını bizzat söylüyor, onlar da hiçbir eksiltme ve artırma yapmaksızın öylece yazıyorlardı. Şayet bir hata vaki olmuşsa, "Cebrail bana gelerek bu ayeti şu surenin filan yerine koymamı emretti." diyerek, onu düzeltiyordu. O, gerek namazlarında, gerekse hutbe, vaaz gibi diğer dînî aktivitelerinde bir veya birkaç sureyi kısmen ya da tamamen okuyor, sahabileri de buna şahit oluyordu. Ayrıca yine o, her yıl Kur'ân'ı -o ana değin vahyedildiği kadarıla- vahiy meleği Cebrail'e bilinen tertibiyle arzediyordu, bu arza bazı sahabiler de iştirak ediyordu. Pek çok sahabinin bir surenin başını, sonunu veya tamamını veyahut da Kur'ân'ın tamamını Hz. Peygamber hayatta iken ezberlediğine ve araştırma konusu yaptığına dair sağlam rivayetler mevcuttur. Onlar bu sureleri, çeşitli münasebetlerle gerek birbirlerine, gerekse Peygamber'e okuyorlardı. Onların hiçbirisinden elimizdeki Mushaf taki ayet sıralamasına aykırı bir görüş nakledilmemiştir. Bütün bunlar, ayetlerin sıralamasının belli bir ölçüye / kurala göre (kıyâsî) değil, tevkîfî olduğunu göstermektedir. ${ }^{143}$

Kadim usulcüler tarafından tam kabul gören bu görüş, ${ }^{144}$ hem tarihi verilere genel olarak uygun düşmesi, hem de Müslümanların ilk ve en kutsal kaynağı durumundaki Kur'ân'ın metnini şüphelerden arındırması, yani güvenilirliğini garanti altına alması bakımından dikkat çekicidir. Bununla birlikte, Kur'ân'ın toplanması (cem') ile ilgili rivayetlere bakılarak, sadece birkaç ayetin Kur'ân konusunda uzman sahabiler tarafından tertip edildiği düşünülebilir. Nitekim İbn Hacer (852/1448), Ebû Bekir döneminde Kur'ân

${ }^{143}$ Mukaddimetü Kitâbi'-mebânî, 39 vd.; ez-Zerkeşî, el-Burhân, I, 237, 256-57; es-Suyûtî, el-İtkân, I, 167-70; ez-Zerkânî, Menâhilü'l-irfân, I, 244-45; Muhammed Hamidullah, Kur'ân-ı Kerîm Tarihi, çev. Salih Tuğ, İstanbul: İFAV, 1993, s. 50; Cerrahoğlu, Tefsir Usulü, 56; Gânim Kaddûrî elHamed, Resmü'l-Mushaf dirâse lügaviyye târîhiye, Bağdat: Menşûrâtü'l-Licneti'l-Vataniyye, 1402/ 1982, s. 120-21; Osman Keskioğlu, Nüzûlünden Günümüze Kur'ân-ı Kerim Bilgileri, 2. bask1, Ankara: T. Diyanet Vakfı Yay., 1989, s. 126; Yıldırım, Kur'ân İlimlerine Giriș, 43; Mennâu'lKattân, Mebâhis fî ulûmi'l-Kur'ân, 139-41; Albayrak, Tefsir Usûlü, 39; Hayrettin Öztürk, Ebedî Mucize Kur'ân, 134; Demirci, Kur'ân Tarihi, 159-62.

${ }^{144}$ Kitâbü'l-mebânînnin müellifi, bu konuyu surelerin tertibi ile birlikte ele alarak, eserini yazmaya başladığı hicrî 425 yılından önce bu konuda görüș beyan eden hemen her alimin, Kur'ân'ın elimizdeki tertip ve düzeninin vahiyle tespit edildiği kanaatinde olduğunu delilleriyle birlikte zikretmekte, sonuç olarak da bu konuda herkesin ittifak ettiğini belirtmektedir. Bkz. Mukaddimetü Kitâbi'l-mebânî, 39 vd. özellikle 46-47'nci sayfalar. 
sayfalar halinde toplanırken, Tevbe Suresi'nin son iki ayeti Hâris b. Huzeyme* tarafından getirildiğinde, o zaman Kur'ân'ı toplama görevi kendisine verilen ve $\mathrm{Hz}$. Osman döneminde kurulacak heyete de başkanlık yapacak olan Zeyd b. Sâbit'e (45/665), Hz. Ömer'in (23/644), "Şayet bunlar üç ayet olsaydı, bunları başlı başına bir sure yapardım. Öyle olmadığına göre, Kur'ân'ın bir suresinin sonuna bakın, bunları oraya ekleyin." demesini kanıt göstererek, bazı ayetlerin sahabilerin içtihatları ile tertip edildiği sonucuna ulaşmaktadır. ${ }^{145}$ İbn Hacer'in görüşüne destek olarak kullandığı bu bilgi, Kur'ân'ın sure sure ayrılmasında sahabilerin sınırlı rolünü göstermesi bakımından da oldukça dikkat çekici görünmektedir.

Gerçi Suyûtî (911/1505), Übey b. Ka'b'ın (21/642) "Rasülüllah bana '...düşünmeyen bir topluluk olduklarından Allah onların kalplerini çevirmiştir.' [Tevbe (9), 127] ayetinden sonra, ...size bir Peygamber geldi... [Tevbe (9), 128-129] şeklinde iki ayet daha okutmuştu." dediğini belirten rivayetin, bu rivayete aykırı olduğunu zikrederek, ${ }^{146}$ İbn Hacer'in görüşünü zayıflatmaya çalışmaktadır. Ne var ki, birçok sahabi bu iki ayeti Hz. Peygamber'den öğrendiğini söylemesine rağmen, Übey'den başka hiç kimse bunların Tevbe Suresi'nin sonuna dahil olduğunu belirtmemektedir. ${ }^{147}$ Bu bilgi İbn Hacer'in görüşünü güçlendirmektedir. Fakat bu, çok basit bir ayrıntı olup, asırlardır Müslümanların elinde bulunan Kur'ân'ın güvenirliğini zedeleyecek bir görüş ayrılığı değildir. O halde bu ve benzeri rivayetlere sı̆̆ınarak, ilâhî hitabın ayetlerinin tertibinin birtakım yanlışlıklar içerdiğini ileri sürmenin, bu sebeple yeniden tertip edilmesini önermenin, ${ }^{148}$ makul ve haklı bir tarafı olamaz. Böyle bir teşebbüs, sırf çok sıradan bir fantezi olarak kalır; Müslümanlar arasında gereksiz yere yeni ihtilaf alanları oluşturmaktan ve sonu gelmez tartışmalarla boşu boşuna zaman kaybettirmekten başka hiçbir işe yaramaz; sanıldığının aksine, Kur'ân'ın daha iyi anlaşılmasına önemli bir katkı da sağlamaz. Öte yandan, bazı usul bilginlerinin, tartışma konusu olan rivayetleri görmezden gelerek, Kur'ân'ın levh-i mahfûzdaki aslının elimizdeki Mushafla aynı tertibe sahip olduğu yönündeki görüşlerinin ${ }^{149}$ de

\footnotetext{
Bu isim bazı rivayetlerde Huzeyme b. Sâbit (es-Suyûtî, el-ittkân, I, 163), bazı rivayetlerde ise, Ebû Huzeyme olarak da geçmektedir (es-Suyûtî, el-ìtkân, I, 161). Bu üç ismin aynı şahsa mı, yoksa farklı şahıslara mı ait olduğunun tespiti, başka bir araştırmada konu edilerek sonuçlandırllabilir.

145 es-Suyûtî, el-ïtkân, I, 169.

146 es-Suyûtî, el-i̇tkân, I, 169. Ayrıca bkz. ez-Zerkânî, Menâhilü'l-irfân, I, 246-47.

147 İlgili rivayetler ve kaynakları için bkz. et-Taberî, Câmiu'l-beyân, XI, 77-78; İbn Kesîr, Tefsîru'lKur'ân, IV, 180-81.

${ }^{148} \mathrm{Bu}$ talihsiz beyan ve öneri için bkz. Ahmet Keleș, Kur'ân'’n Cem’i ve Tertibi Kur'ân Ayetlerinin Tevkîfiliği Konusundaki Buhârî Hadislerine ve Kur'ân İlimlerindeki Rivayetlere Eleştirel Bir Yaklaşım, "İslâmî Araştırmalar", cilt: XIV (ss. 103-126), sayı:1, 2001, Ankara: TEKDAV, s. 118-25.
} 
kabul edilebilir olduğunu söylemek gerçekten zordur. Kur'ân'ın levh-i mahfûzda Arapça olarak mı bulunduğunun, yoksa Hz. Peygamber'e indirilirken mi Arapça'ya çevrildiğinin bilinmemesi, bu zorluğu daha da artırmaktadır. Üstelik levh-i mahfûz kavramı bizim için tam bir gayb alanını ifade etmektedir; dolayısıyla, Kur'ân'ın aslının orada ne şekilde bulunduğunu bilmemize imkan yoktur. Levh-i mahfûzla ilgili rivayetleri, "Kur'ân'ın içerdiği mesaj, aslı (özü, manası: insanî dile çevrilmemiş şekli) itibariyle Allah katında mevcuttur." şeklinde yorumlamak, belki daha doğru olabilir.

Ayetlerin sıralaması kadar diğer bir tartışma konusu da surelerin sıralamasıdır. Genel kabul gören tanıma göre, ayetlerden meydana gelen, başlangıç ve bitiş noktası bulunan Kur'ân bölümlerine sure adı verilmektedir. ${ }^{150}$ Bugün elimizde bulunan Kur'ân metni 114 sureden müteşekkildir. Usulcüler bu ayırımın, ezberlemeyi kolaylaştırması, okuyucunun bıkmasını önlemesi, ilâhî kelamı daha iyi anlaşılmaya elverişli hale getirmesi gibi birçok faydasından ve hikmetinden bahsetmektedirler; ${ }^{151}$ fakat bu ayırımın tamamen tevkîfî olduğunu iddia etmemektedirler. Zaten surelerin sayısı hakkında sahabilere nispet edilen farklı görüşler, ${ }^{152}$ Tevbe Suresi'nin son iki ayetini İbn Huzeyme'nin getirmesi olayı etrafında sahabiler arasında yapılan tartışmalar -ki, biz bunlara yukarıda kısmen temas ettik-, genel kabul görmese bile, Tevbe Suresi'nin Enfâl Suresi'nin, ${ }^{153}$ Kureyş Suresi'nin de Fîl Suresi'nin devamı olduğu yönündeki değerlendirmeler -ki, ismi geçen surelerin birbiriyle bağlantısı açısından bunlar hiç de görmezlikten gelinecek değerlendirmeler değildir-, ${ }^{154}$ böyle bir iddiayı zayıflatacaktır. Bu yüzden, elimizdeki Mushafta bulunan surelerin müstakil birer sure olarak tanımlanmasının çoğunluk itibariyle tevkîfî olduğunu söylemek, kanaatimizce daha doğru olacaktır. Allah'ın ayetlerinin Arap diliyle ifade edilmesi ve sıralanması konularında olduğu gibi, buradaki tevkîfiliğin, önemli oranda vahiy, kısmen de Peygamber kaynaklı olduğu varsayılabilir.

Keleş'in bu makalesinde ulaştı̆̆ı sonuçları, geneli itibariyle kabul etmemekle birlikte, “ayetlerin nüzul sebepleri çerçevesinde gruplar ve pasajlar halinde tespit edilmesi" önerisini destekliyoruz.

149 ez-Zerkeşî, el-Burhân, I, 236; es-Suyûtî, el-ìtkân, I, 170.

150 ez-Zerkeşî, el-Burhân, I, 264; ez-Zerkânî, Menâhilü'l-irfân, I, 247; Cerrahoğlu, Tefsir Usulü, 57; Keskioğlu, Kur'ân-ı Kerim Bilgileri, 127; Yıldırım, Kur'ân İlimlerine Giriş, 52; Mennâu'l-Kattân, Mebâhis fì ulûmi'l-Kur'ân, 139.

151 Bkz. ez-Zerkeşî, el-Burhân, I, 264-65; ez-Zerkânî, Menâhilü'l-irfân, I, 247-48.

152 Ebu'l-Ferec Cemalüddin Abdurrahman b. Ali b. Muhammed el-Cevzî el-Kuraşî el-Bağdâdî, Acâibü ulûmi'l-Kur'ân, thk. Abdulfettâh Âşûr, Kâhire: ez-Zehrâ' li'l-i'lâmi'l-Arabî, 1415/1995, s. 12224; Keskioğlu, Kur'ân-ı Kerim Bilgileri, 128.

153 el-Mâverdî, en-Nüket ve'l-uyûn, II, 336-37.

154 et-Taberî, Câmiu'l-beyân, XXX, 306-07; İbn Kesîr, Tefsîru'l-Kur'ân, VIII, 512-13. 
Fakat surelerin isimlendirilmesi konusunda aynı şeyi söylemek zordur. Çünkü her ne kadar vahyedilen ayetlerin hangi surenin neresine yazılacağ1nı bizzat söylemesinden ve Fâtiha Suresi hakkında "O, Kitâbın [Kur'ân'ın] başlangıcıdır (fâtiha)." demesinden, Hz. Peygamber'in bazı sureleri isimlendirdiği veya en azından adlandırmaya temel teşkil edecek şekilde nitelendirdiği anlaşllyorsa da, surelerin hepsini onun isimlendirdiğini gösteren herhangi bir bilgi mevcut değildir. Oysa hem Kur'ân'ın Hz. Ebû Bekir ve Osman dönemlerinde toplanması sürecinde yaşananlardan, hem Übey b. Ka'b ve İbn Abbas (68/687) gibi Kur'ân'ı özel gayretleriyle Mushaf haline getiren sahabilerden ${ }^{155}$ nakledilenlerden, hem de konuyla ilgili diğer rivayetlerden, çoğu sahabinin sureleri isimleriyle bildikleri, hatta bazı sureleri birden fazla isimleriyle tanıdıkları anlaşılmaktadır. Konuyla ilgili kesin yargıya ulaşmamızı engelleyen sorun, onların surelere bu isimleri kendilerinin mi verdiklerinin, yoksa Hz. Muhammed'den mi öğrendiklerinin belli olmamasıdır. Kesin olan tek şey, Fâtiha Suresi ile ilgili bazı varsayımlar müstesna, elimizdeki Kur'ân'ın surelerine bu isimlerin ilâhî irade tarafından verildiğini gösteren herhangi bir ayetin veya rivayetin bulunmamasıdır. Üstelik usulcülerin açıklamalarından, İslâm alimlerinin birçok sureyi asıl isminin yanı sıra daha başka isimlerle de isimlendirdikleri anlaşılmaktadır. O halde bu konunun Peygamber'e dayanacak şekilde kısmen tevkîfí olabileceği, surelerin genellikle sahabiler tarafından isimlendirildiği, bazı İslâm alimlerinin yaptığı isimlendirmenin ise, asıl isimlerle değil, ikinci, üçüncü... isimlerle ilgili olduğu söylenebilir. Hangi türden olursa olsun, surelerin isimlendirilmesinde, onların konuları, başlangıç harfleri ve kelimeleri, içerdikleri kıssalar ve peygamber isimleri vb. hususlar belirleyici olmuştur. ${ }^{156}$

Birbirinden ayrılmaları ve isimlendirilmeleri bu şekilde gerçekleşen surelerin tertibi konusunda da usulcüler farklı görüşler ortaya atmışlardır. Onlar, sureleri iki açıdan sıralamaya tabi tutmuşlardır. Bunlardan birisi nüzul sıralaması, diğeri yazım (te'lîf) sıralamasıdır. Usulcüler Kur'ân'ın nüzul sırasını ortaya koyabilmek için, öncelikle surelerin Mekkî mi, yoksa Medenî mi olduklarını belirlemeye çalışmışlardır. Fakat bir surenin Mekkî ya da Medenî olduğuna karar verebilmek için, o surenin indiği yerin mi, hitap ettiği yöre halkının mı, yoksa Hz. Peygamber'in Medine'ye hicretinin mi kriter alınması

${ }^{155}$ Bu kişisel Mushaflar hakkında kısa bilgi ve değerlendirmeler için bkz. Hayrettin Öztürk, Ebedî Mucize Kur'ân, 111-122.

156 Surelerin isimlendirilmesi hakkında geniş bilgi için bkz. ez-Zerkeşî, el-Burhân, I, 260-62, 26972; es-Suyûtî, el-İtkân, I, 147-58; Cerrahoğlu, Tefsir Usulü, 59; Yıldırım, Kur'ân İlimlerine Giriş, 53-54. 
gerektiği konusunda anlaşmazlığa düşmüşlerdir. Meşhur olan görüş, hicretin esas alınması gerektiği yönündedir. Usulcüler, surelerin nüzul sıralamalarını bu esasa göre yapmaya çalışmışlar, bu bağlamda Mekkî ve Medenî sure ve ayetlerin özelliklerini belirleme ve bunlar arasındaki farkları ortaya koyma hususunda büyük gayretler sarfetmișlerdir. Ne var ki, böyle bir kriterin esas alınması, sıralama ile ilgili sorunların tamamen aşılması anlamına gelmemektedir. Zira kimi surelerin Mekkî mi, yoksa Medenî mi olduklarının bu kritere rağmen tartışmalı olması; bazı surelerden hangisinin diğerinden önce ya da sonra vahyedildiğinin tam olarak belirlenememesi; içerisinde hem Mekkî, hem de Medenî ayetler bulunan birçok surenin, inmeye başladığ 1 döneme göre mi, yoksa ayetlerinden çoğunun indiği döneme göre mi Mekkî veya Medenî olduğuna karar verileceğinin belli olmamasi; haddinden fazla sorun ortaya çıkarmaktadır. Birçok ayetin nüzul döneminin bilinmemesi ise, nüzul sıralamasını zorlaştıran ayrı bir sorun olarak usulcülerin karşısına çıkmaktadır. Bütün bunlar, surelerin nüzul sırasını tespit etmeyi zorlaştıran unsurlardır. Zaten bu hususta sahabilerin ve tâbiîlerin söylediklerine dayanılmış olup, Hz. Peygamber'den herhangi bir söz nakledilmemiştir. ${ }^{157}$

Bu bahse son vermeden önce belirtmeliyiz ki, verdiğimiz bu bilgilerden, surelerin iniş sıralamasının önemini azalttığı gibi bir anlam çıkarılmamalıdır. Tam aksine, surelerin, özellikle de ayetlerin iniş sıralarının -mevcut imkanların elverdiği ölçüde de olsa- bilinmesi, Kur'ân'1, varlıktan, toplumdan, tarihten kopuk bir metin olarak değil, tarihin içinde, toplumdaki inkişaf sürecini izleyen canlı yapısı içerisinde okunmasını, bu sebeple ilâhî hitabın daha iyi anlaşılmasını kolaylaştırması açısından oldukça önemlidir. ${ }^{158}$ Zira Kur'ân'ın sosyal/tarihi bağlamı ile paralel olarak anlaşılmasının, birbiriyle çelişiyor gibi görünen ayetlerin (müsskilü'l-Kur'ân) uzlaştırılmasında, ayetlerin nâsih ve mensûhlarının, mücmel ve mübeyyinlerinin belirlenmesinde, bir kötülüğü kaldırmada veya bir iyiliği yerleştirmede toplum psikolojisine uygun olarak izlenen aşamalı (tedrî $\hat{\imath})$ metodun tespit edilmesinde özel bir öneme sahip olduğunu özellikle vurgulamalıyız. Bu tespitler yapıldığı zaman, Kur'ân'ın önemli bir bölümünün doğru olarak anlaşılıp yorum-

157 Geniş bilgi için bkz. ez-Zerkeşî, el-Burhân, I, 187 vd.; es-Suyûtî, el-i̇tkân, I, 34 vd.; ez-Zerkânî, Menâhilü'l-irfân, I, 140 vd; Subhî es-Sâlih, Mebâhis fî ulûmi'l-Kur'ân, 164 vd. (Türkçe'si için bkz. Kur'ân İlimleri, 133 vd); Yıldırım, Kur'ân İlimlerine Giriş, 43-52.

Hz. Osman, İbn Abbas ve Cafer es-Sâdık Mushaflarının nuzul sıralamaları arasındaki farkları karşılaştırmalı olarak gösteren bir tablo için bkz. Cerrahoğlu, Tefsir Usulü, 86-87.

158 Albayrak, Tefsir Usûlü, 41. 
lanmasının yolu açılmış demektir. Usul ve tefsir kitaplarımız bunun örnekleriyle doludur.

Kur'ân'ın anlaşılmasına önemli katkılar sağlayan nüzul sıralaması meselesinde olduğu gibi, surelerin Osman Mushafi'ndaki (el-İmâm) yazım sıralaması -ki, buna Mushaf stralaması adı da verilmektedir- ${ }^{159}$ konusunda da usulcülerin farklı görüşler ileri sürdükleri görülmektedir. Bu konuda onlardan üç farklı görüş nakledilmiştir. Birinci görüşe göre, surelerin sıralaması tevkîfîdir; yani sureler Allah ve/veya Peygamberi tarafından sıralanmış, bu sıralama Hz. Muhammed tarafından ümmete bildirilmiştir; insanlar bu konuda akıl yürüterek yeni bir sıralama yapma değil, susma ve olanı kabul etme sorumluluğuyla karşı karşıyadırlar. İkinci görüşe göre ise, surelerin sıralaması sahabilerin içtihatları ile gerçekleşmiştir. Zerkeşî bu görüşlerden birincisinin İslâm alimlerinin çoğunluğunun görüşü olduğunu belirtirken, ${ }^{160}$ Suyûtî ikinci görüşün genel kabul gördüğünü iddia etmektedir. ${ }^{161}$ Ancak Zerkeşî, sahabilerin içtihatlarının fiili olarak yalnızca Hz. Peygamber'den duyduklarına ve öğrendiklerine dayandığını, dolayısıyla bu iki görüş arasında isim farkından başka bir fark bulunmadığını ileri sürmektedir. ${ }^{162}$ Oysa Hz. Peygamber'den veya sahabilerinden, surelerin tamamının ilâhî denetim altında sıralandığını doğrudan veya dolaylı olarak gösteren herhangi bir rivayetin gelmemesi, aksine, bazı rivayetlerde sahabilerden bir kısmının birkaç surenin sıralanmasındaki rollerine işaret etmesi, bu görüşleri de, Zerkeşînnin onları uzlaştırma ve birleştirme çabalarını da zayıflatmaktadır. ${ }^{163}$

Muhammed Hamidullah (ö. 2002), Hz. Peygamber'in her yil Cebrail'le Kur'ân'ı mukabele etmesini ( $a r z a$ ) ve ömrünün son yılında bunu iki defa yapmış olmasını (el-arzatü'l-ahîra) delil göstererek, surelerin tertibinin tevkîfí olduğunu savunsa da, ${ }^{164}$ bu iddia tarihi dayanaktan yoksun görünmekte-

159 Mesela, Suyûtî’nin el-İtkân isimli eserindeki bir başlı̆̆ ‘Übey ve İbn Mes’ûd Mushaflarının Tertîbî Hakkında' şeklindedir (I, 175).

160 ez-Zerkeşî, el-Burhân, I, 257.

161 es-Suyûtî, el-ìtkân, I, 170.

162 ez-Zerkeşî, el-Burhân, I, 257. Ayrıca bkz. es-Suyûtî, el-ìtkân, I, 171-72.

163 Zerkânî, sure sıralamasının Hz. Peygamber'e dayandı̆̆ını, dolayısıyla tevkîfî olduğunu savunan görüşe üç noktadan hareketle karşı çıkmaktadır: 1- Delil olarak gösterilen rivayetler, surelerin tamamının tevkîfî olduğunu garanti etmemekte ve bu konuda kesin bilgi içermemektedir. 2İbn Abbas'tan gelen rivayetler, Enfâl, Tevbe ve Yûnus surelerinin tertibi hususunda Hz. Osman'ın içtihat ettiğini göstermektedir. 3- Bu konuda sahabilerin icmâ etmesi, hepsinin bunu doğru kabul etmesinden değil, ümmetin birliğini düşünmelerinden, niza ve fitneye yol açmama hususundaki hassasiyetlerinden kaynaklanmaktadır (ez-Zerkânî, Menâhilü'l-irfân, I, 251).

${ }^{164}$ Hamidullah, Kur'ân-ı Kerîm Tarihi, 50-51. Kur'ân tarihiyle ilgili araştırmalar yapan değerli bilim adamlarımızdan Hayrettin Öztürk de benzer argümanları kullanarak, surelerin sıralamasının tevkîfî olduğu sonucuna ulaşmaktadır. Geniş bilgi için bkz. Hayrettin Öztürk, Ebedî Mucize Kur'ân, $134-41$. 
dir. Zira, atıf yapılan mukabelelerde surelerin şu anda elimizde bulunan sıralamasının mı, yoksa farklı bir sıralamanın $\mathrm{m}$ izlendiğini gösteren herhangi bir açıklık mevcut değildir. Üstelik Zeyd b. Sâbit, surelerin sıralamasını son mukabelede hazır bulunduğuna atıfla yaptığını belirten en küçük bir imada dahi bulunmamıştır. Sure sıralamasının tevkîfî olduğunu savunan eski alimlerin, bu argümana hiç başvurmamaları da oldukça şaşırtıcıdır. Öte yandan, eğer sıralama son mukabele esas alınarak yapılmış olsaydı, buna bütün sahabiler muvafakat gösterirler, hiçbiri farklı sıralama yapmazdı. Oysa elimizdeki bilgiler, Übey b. Ka’b ve İbn Mes'ûd (32/652) gibi bazı sahabilerin, surelerini İmam Mushaftan farklı tertip ettikleri kişisel Mushaflara sahip olduklarını göstermektedir. ${ }^{165}$ Hatta ciddi bir inceleme ile, Ebû Bekir Mushafı ile Osman Mushafı'nın aynı kişi -Zeyd- veya onun başkanlığındaki bir heyet tarafından gerçekleştirilen sure tertiplerinin bile birbirinden farklı olduğunu tespit etmek zor değildir. ${ }^{166}$ Şayet surelerin sıralaması tevkîfî olsaydı, ne bu iki Mushaf, ne de Osman Mushafı ile kişisel Mushaflar arasında farklılık olurdu. ${ }^{167}$ Ayrıca, Tevbe (Berâe) Suresi'nin şu anki yerine Hz. Osman tarafından yerleştirildiğini haber veren ciddi tarihi bilgiler bulunmaktadır. ${ }^{168}$ Öte yandan, Muavvizeteyn, yani Felak ve Nâs sureleri İbn Mes'ûd'un Mushafinda yer almamakta, gerek bu sahabinin, gerekse Übey b. Ka'b'ın Mushaflarında Allâhümme innâ nesteînüke... ve Allahümme iyyâke na'büdü... şeklinde başlayan iki kısa bölüm bulunmakta, ${ }^{169}$ bazı rivayetlerde bunların Hafd ve Hal' Sureleri biçiminde adlandırıldığı belirtilmekte, hatta Hz. Ali'nin bunlardan 'Allah'ın Peygamberi'nin kendisine öğrettiği iki sure' diye söz ettiği bildirilmektedir. ${ }^{170}$

Zerkeşî̀ye göre, yukarıda adı geçen sahabileri destekleyen herhangi bir delil bulunmamaktadır. ${ }^{171} \mathrm{O}$, Übey'in dua ve tevil kabilinden ifadeleri Mushafına aldığını belirten rivayetlere atıf yaparak, onun Mushafında Allâhümme innâ nesteînüke... ve Allahümme iyyâke na'büdü... pasajlarının yer almasını da bu bağlamda görmek gerektiğini savunmaktadır. İbn Mes'ûd'a isnat edilen ve Muavvizeteyn ile Fâtiha Suresi'nin Kur'ân'dan olmadığını bildiren rivayetleri ise, Übey b. Ka'b, Nevevî ve İbn Hazm'a dayanarak reddetmekte,

\footnotetext{
165 es-Suyûtî, el-ìtkân, I, 175.

166 Muhsin Demirci, Tefsir Usulü, 3. bask1, İstanbul: İFAV, 2003, s. 107.

167 Demirci, Tefsir Usulü, 83, 85-86.

168 Şihâbüddîn Abdurrahmân b. İsmâîl Ebû Şâme el-Makdisî, el-Mürşidü'l-vecîz ilâ ulûm teteallaku bi'l-Kitâbi'l-azîz, thk. Tayyar Altıkulaç, 2. baskı, Ankara: T. Diyanet Vakfı Yay., 1406/1986, s. 61.

169 ez-Zerkeşî, el-Burhân, I, 251; es-Suyûtî, el-ïtkân, I, 178-79.

170 es-Suyûtî, el-ìtkân, I, 178-79.

171 ez-Zerkeşî, el-Burhân, I, 251.
} 
bunların uydurma olduklarını ileri sürmektedir. ${ }^{172}$ Fakat yine de bu rivayetlerin sahih olabileceğini göz ardı etmemiş olmalı ki, eserinin başka bir yerinde İbn Mes'ûd'un görüşünden döndüğü iddiasını gündeme getirmektedir. ${ }^{173}$ Kanaatimizce, bu sureleri Mushafa dahil etmemekle, Allah tarafindan vahyedilmediğini söylemek farklı iddialardır. İbn Mes'ûd'dan, bu surelerin vahiy unsuru olmadıklarına dair en küçük bir ima dahi vaki olmamıştır. O halde hepsi de Kur'ân konusunda gerçek birer otorite olan bu sahabilerin tavırlarını başka nedenlere hamletmek en doğrusudur. Belki, 'Yemin olsun ki, Biz sana sürekli tekrarlanan yedi [ayeti] ve yüce Kur'ân'ı verdik. ${ }^{174}$ ayetine dayanarak, Fâtiha'yı Mushaf'tan ayrı bir vahiy kabul ettikleri, diğer iki sureyi de vahiy ürünü olmakla birlikte Mushaf ta yer alması gerekmeyen birer dua olarak düşündükleri varsayılabilir. Zerkeşî, adı geçen sahabilerin Mushaflarına ilişkin bazı değerlendirmelerinde haklı görünse de, yukarıda verilen bilgiler, -en azından ihtilaflara işaret etmesi bakımından- surelerin tertibi bağlamında değerlendirmeye alınabilecek bilgilerdendir.

Özetlemeye çalıştığımız bu görüş ayrılıkları karşısında esasen İbn Atiyye'ye (546/1151) ait olan üçüncü bir görüş büyük önem kazanmaktadır. Onun görüşüne göre, Kur'ân'ın baş tarafında yer alan yedi uzun surenin, Hâ-Mîm harfleriyle başlayan surelerin ve kısa surelerin sıralamalarında olduğu gibi, surelerin çoğunun gerek gruplar halindeki, gerekse Kur'ân içerisindeki tertibi Rasülüllah hayatta iken bilinmekteydi; diğer surelerin tertibi ise, ümmete [ilk muhatap olmaları hasebiyle sahabilere] havale edilmiştir. Onun gerçekten makul görünen bu görüşü, sonraki İslâm alimlerinin önde gelenleri tarafından da benimsenmiştir. ${ }^{175}$ Ancak hangi surelerin sıralamasının tevkîfî, hangilerinin içtihâdî olduğu bu alimler arasında tartışmalıdır. ${ }^{176}$

İbn Atıyye'in bu bakış açısı, "Surelerin bu sıralaması, ayetlerin sıralaması gibidir. O halde kim bir sureyi öne alır veya geriye bırakırsa, Kur'ân'ın nazmını bozmuş olur.", "Surelerin bu şekildeki sıralaması, Allah katında levh-i mahfûzda da böyledir.", "Eğer Kur'ân bir defada inseydi, aynen bu tertip üzere inerdi." vb. türden aşırı söylemlere ${ }^{177}$ karşı orta bir yolu temsil etmektedir. Yine bu bakış açısı, '...öyleyse onun gibi on sure getirin.' [Hûd (11), 13] ayetinin "Bakara'dan Hûd Suresi'ne kadar on sure getirin." şeklinde,

\footnotetext{
172 ez-Zerkeşî, el-Burhân, II, 128.

173 ez-Zerkeşî, el-Burhân, I, 251.

174 Hicr (15), 87.

175 ez-Zerkeşî, el-Burhân, I, 244-46; es-Suyûtî, el-ìtkân, I, 173-74; ez-Zerkânî, Menâhilü'l-irfân, I, 251-52.

176 ez-Zerkânî, Menâhilü'l-irfân, I, 251.

177 Bu görüşler için bkz. ez-Zerkeşî, el-Burhân, I, 259-60; es-Suyûtî, el-İtkân, I, 171.
} 
'Kur'ân'ı tane tane oku' [Müzzemmil (73), 4] ayetinin, "Onu bu tertip üzere okuyun." biçiminde anakronik ve yanlış anlaşılmasını da engellemektedir. ${ }^{178}$ Öte yandan Übey ve İbn Mes'ûd'un (32/652), Hz. Peygamber'in çeşitli hadislerine ve uygulamalarına dayanarak, Mushaflarını gerek birbirlerinden, gerekse Osman Mushafi'ndan daha farklı tertip etmeleri de, ${ }^{179}$ surelerin tertibi konusunun aşırı büyütülmemesi gerektiğini ortaya koyması bakımından İbn Atıyye'nin haklılığını perçinlemektedir. Yani surelerden çoğunun tevkîfen, önemli bir kısmının ise, içtihâden, yani sahabilerin görüşlerine dayanılarak sıralandığı söylenebilir.

$\mathrm{Bu}$ arada yeri gelmişken belirtmemiz gerekir ki, surelerin tertibi ister kısmen, ister tamamen tevkîfî olsun, neticede İslâm tarihi boyunca Müslümanlar, Hz. Osman'ın oluşturduğu ilmî heyetin hiçbir eksiltme ve artırma yapmaksızın ilâhî kelamı Mushaf haline getirdiğine inanmışlar, bu heyetin cem ettiği Kur'ân'ı muteber kabul etmişlerdir. ${ }^{180}$ Kur'ân'ın tertip edilmiş metnine duyulan bu güven, yüzyllardan beri süregelen tefsir geleneğinin ürünlerinden de anlaşılacağı üzere, surelerin ve ayetlerin sırasıyla ele alınarak yorumlanması sonucunu doğurmuştur. İlgili bölümdeki konu bütünlügü̈ne bakmaksızın bir ayetin bütün inceliklerini ele almasına imkan tanıması açısından müfessire, aradığı ayetin tefsirinin kolayca bulabilmesini sağlaması bakımından da okuyucuya ve araştırmacıya avantaj sağlayan bu usul, gereksiz tekrarlara ve amacını aşan bıktırıcı uzun tahlillere yol açması dikkate alınarak eleştirilebilir. Ancak burada yeri gelmişken belirtmeliyiz ki, bu usulün parçacı yaklaşıma sebep olduğunu iddia etmek, gerçekten haksızlık olur. Çünkü müfessirler Kur'ân'ın her şeyden önce yine Kur'ân'la tefsir edilmesi gerektiği yönündeki usul kaidesinden hareketle, bir ayeti ilgili diğer ayetleri de zikrederek açıklamak suretiyle ayetler arasındaki bütünlüğü ortaya koymaya gayret etmişlerdir. ${ }^{181}$ Bu noktada belki bunun yeterli düzeyde yapılıp yapılmadığ tartışılabilir.

Klasik usulcülerin sıralama ilgili olarak üzerinde durdukları diğer bir konu da surelerin gruplara ayrılmasıdır. Onlar, Hz. Peygamber'in "Tevrât'ın yerine bana yedi uzun [sure] (es-seb'u't-tıvâl), İncil'in yerine yüz [civarında ayeti bulunan sureler] (el-miûn), Zebûr'un yerine ikili [sureler] (el-mesânî), faz-

\footnotetext{
178 ez-Zerkeşî, el-Burhân, I, 259.

${ }^{179}$ Her iki sahabiye ait Mushafların tertiplerini gösteren tam bir liste için bkz. es-Suyûtî, el-i̇tkân, I, 175-76. Bunları Osman Mushafi'nın tertibi ile mukayese eden bir liste için bkz. Cerrahoğlu, Tefsir Usulü, 84-85.

180 ez-Zerkeşî, el-Burhân, I, 236; Hamidullah, Kur'ân-ı Kerîm Tarihi,51; el-Hamed, Resmü’l-Mushaf, 122-23.

181 İbn Kesîr, Tefsîru'l-Kur'âni'l-Azîm, I, 12-13.
} 
ladan da çok duraklı / kısa ayetli [sureler] (el-mufassal) verildi." anlamındaki bir hadisine dayanarak, Kur'ân'ı dört gruba ayırmışlar, fakat bu gruplara hangi surelerin dahil olduğu hususunda anlaşamamışlardır. Usulcülerin çoğu tarafından kabul edilen tasnife göre, Bakara Suresi'nden Yûnus Suresi'ne kadar seb-i tıvâl, Yûnus Suresi'nden itibaren ayet sayısı 100 civarında veya daha fazla olan sureler miûn, bunlardan sonra gelip, Kâf Suresi'ne kadar devam eden sureler mesânî, Kâf Suresi'nden Nâs Suresi'ne kadar mufassal grubu içerisinde yer almaktadır. ${ }^{182}$ Bu arada Bakara ile Âl-i İmrân surelerine Zehrâvân, Felak ve Nâs surelerine Muavvizetân, Hâ-Mîm harfleri ile başlayan surelere Havâmîm denilmesi vb. örneklerde olduğu gibi, iki veya daha fazla surenin bir grupta toplandığı da görülmektedir. ${ }^{183}$ Fakat gerek birinci türdeki, gerekse bu türdeki sıralamalar teknik bilgiler kabilinden olup, bunların tefsir ilminin şekillenmesinde ve gelişmesinde önemli bir etkisi olmamıştır.

\section{b. Resmi}

Osman Mushafi'nda harfler, noktasız ve içi boş (Sîn harfinin dişlerinin yazılmaması gibi) olarak yazılmıştı; kelimelere hareke konmamıştı; sureleri, ayetleri ve cümleleri birbirinden ayıracak işaretler yoktu. Bunlar olmayınca noktalama işaretlerinin de tabii olarak bulunmadığı Osman Mushafi'nda surelerin isimleri bile yer almamıştı. ${ }^{184}$ Ayrıca konması gereken birçok uzatma harfi metne konmamış, bazı kelimelere hiç okunmayan fazlalık harfler eklenmişti. ${ }^{185}$ Bu yazım özellikleriyle Osman Mushafı, her şeyden önce Kur'ân'daki ayet sayısı hakkında yukarıda değindiğimiz gibi, görüş birliği sağlanamamasının ${ }^{186}$ nedenini önemli ölçüde açıklamaktadır. Çünkü esas alınan Mushaf ta ayetleri birbirinden ayıracak işaretler ve numaralar bulunmadığından, diğer bir ifadeyle, numaralandırılma sonradan yapıldığından, ayetlerin sayısı birçok alime göre az da olsa değişiklik arzetmektedir.

\footnotetext{
182 ez-Zerkeşî, el-Burhân, I, 257; es-Suyûtî, el-i̇tkân, I, 172; ez-Zerkânî, Menâhilü’l-irfân, I, 248-49; Keskioğlu, Kur'ân-ı Kerim Bilgileri, 128.

183 ez-Zerkeşî, el-Burhân, I, 258; Yıldırım, Kur'ân İlimlerine Giriş, 53-54.

184 Osman Mushafı'nın yazı özellikleri hakkında derli-toplu bilgi için bkz. Cerrahoğlu, Tefsir Usulü, 88-92; Muhammed b. Muhammed Ebû Şehbe, el-Medhal li dirâseti'l-Kur'ân, et-tab'atü's-sâniye, Kahire: Mektebetü's-sünne, 1416/1996, s. 251, 254; Mennâu'l-Kattân, Mebâhis fí ulûmi'l-Kur'ân, 148-52.

185 Örnekler için bkz. ez-Zerkeşî, el-Burhân, I, 380 vd.; ez-Zerkânî, Menâhilü'l-irfân, I, 260 vd.

${ }^{186}$ Farklı görüşler için bkz. ez-Zerkeşî, el-Burhân, I, 249; es-Suyûtî, el-İtkân, I, 180-88; ez-Zerkânî, Menâhilü'l-irfân, I, 242.
} 
Yine bu yazım özellikleriyle Osman Mushafı, gerek bazı kelimelerin, gerekse onların cümle içinde takdir edilecek konumlarına göre sonlarının faklı şekillerde harekelenmesine, yazılmayan uzatan harflerin takdir edilip edilmemelerine bağlı olarak ilgili kelimelerin farklı biçimlerde okunmasına, Bâ ve Nûn gibi, noktaları yazılmadığında şekilleri aynı olan harflerin çok az da olsa birbirinin yerine ikame edilmesine yol açmıştır. Bütün bunlardan ötürü usulcüler, Osman Mushafi'nın farklı okuma biçimlerine imkan sağlayacak özel bir yazım tekniği ile yazıldığını belirtmişlerdir. ${ }^{187}$ Kıraat olgusunu yalnızca yazının imkanı ile izah etmenin zorluğu ortadadır. Bir kıraatin kabul edilebilmesi için sadece İmâm Mushaf'nn yazı tekniğinin buna imkan vermesi elbette yeterli değildir; o kıraatin aynı zamanda mütevatir (veya bazı alimlere göre meşhur) bir senetle rivayet edilmiş olması, Arap dilinin kurallarına ve Osman Mushafı'na uyması da şarttır. Aksi halde keyfiliklerin önüne geçilemeyeceği aşikârdır. Bu şartlara uyan on farklı kıraat İslâm aleminin her tarafında gerek ibadet, gerekse ilmi incelemeler için genel kabul görmüştür. Bunların mütevatir olanları, İbn Âmir (118/736), İbn Kesîr (120/ 738), Âsım (127/745), Ebû Amr (154/771), Hamza (156/773), Nâfi' (169/ 785) ve Kisâî’nin (189/805) kıraatleridir. Meşhur olanları ise, Ebû Ca'fer (130/747), Ya'kûb (205/820) ve Halef'in (229/843) kıraatleridir. Bunların yanı sıra şâz kabul edilen kıraatlere de gereken tolerans gösterilmiştir. ${ }^{188}$ Müfessirler de tefsirlerinde kıraat farklılıklarına dayanarak, ayetlerin anlam zenginliğini ve derinliğini ortaya çıkarmak suretiyle, ilâhî mesajın en geniş anlam yelpazesine ulaşmaya gayret göstermişlerdir. Gerçekten onların telif ettikleri tefsirler bunun örnekleriyle doludur.

Ancak bu kadar faydasına rağmen, kıraat olgusundan kaynaklanan çok önemli bir sorunun varlı̆̆ı da inkâr edilemez. Bahsi geçen on kıraatten yalnızca bir tanesinin mi, yoksa hepsinin mi Kur'ân kabul edileceği gerçekten önemli bir sorun olagelmiştir; çünkü bu sorunun çözümü, Kur'ân'dan anlaşılması gereken ilk anlamı ve ibadette tercih edilmesi gereken kıraati doğrudan etkilemektedir. Zerkeşî "Kur’ân ve kıraat iki farklı gerçektir. Kur’ân, be-

\footnotetext{
187 ez-Zerkânî, Menâhilü'l-irfân, I, 262-64.

${ }^{188}$ Kırâat, çeşitleri ve imamları hakkında geniş bilgi için bkz. Ebû Şâme el-Makdisî, el-Mürşidü’lvecîz, 146 vd.; ez-Zerkeşî, el-Burhân, I, 318 vd.; es-Suyûtî, el-İtkân, I, 197 vd.; ez-Zerkânî, Menâhilü'l-irfân, I, 289 vd.; Cerrahoğlu, Tefsir Usulü, 102 vd.; Mehmet Ünal, Kur'ân'ın Anlaşılmasında Kıraat Farklılıklarının Rolü, Basılmamış doktora tezi, Ankara: A.Ü. Sosyal Bilimler Enstitüsü, 2002, s. 10 vd.

Not: Mehmet Ünal'ın adı geçen doktora tezi Fecir Yayınları tarafından aynı isimle basılmasına (Ankara, 2005) rağmen, biz yine de basılmamış nüshayı kullanmak zorunda kaldık. Çünkü atıf yaptığımız bölümler baskı esnasında eserden çıkarılmıştır.
} 
yan ve i'câz için Muhammed'e (S.A.S.) indirilen vahiydir. Kıraat ise, harflerin yazılışlarına ve şekillerine bağlı olarak bu vahyin lafızlarının şeddeli ve şeddesiz vb. biçimlerde farklılaşmasıdır." diyerek, ${ }^{189}$ bu sorundan kurtulmaya çalışmaktadır. Zerkeşînnin söylediği, tabiî ki, gerçeğin ta kendisidir. Ne var ki, sorun, böyle bir akıl yürütmeyle aşllamayacak kadar nazik bir durum arzetmektedir. Zira Hz. Muhammed'e indirilen vahyi bugün itibariyle bizzat tespit etme imkanından mahrumuz; elimizde onun sahabilerinin tespit edip, üzerinde görüş birliğine ulaştıkları gerçek bir Kur'ân metni olarak Osman Mushafı bulunmaktadır. Bu yüzden, tartışmanın vahiy üzerinden değil, bu metin üzerinden yürütülmesi gerekmektedir. Gazâlî’nin (505/ 1111) dediği gibi, Osman Mushafi'nın iki kapağı arasında neler yer almışsa bunların hepsi de vahiydir. ${ }^{190}$ Ancak Mushafta kayıtlı bulunan bu vahyin farklı şekillerde okunduğu da bir gerçektir. Bu noktada İbnü's-Salâh (643/ 1245), bir kıraatin Kur'ân sayılabilmesi için Hz. Peygamber'den tevatür yoluyla rivayet edilmesinin şart olduğunu belirttikten sonra, yedi mütevatir kıraatin bu şartı taşıdığını söylemekte, ${ }^{191}$ böylece bu yedi kıraatin hepsinin de Kur'ân olduğuna işaret etmektedir. Zerkânî (1948) ise, üç meşhur kıraati de bunlara ekleyerek, toplam on kıraatin Kur'ân olduğunu ileri sürmektedir. ${ }^{192}$ Oysa aynı müellif, Hasan el-Basrî (110/728), İbn Muhaysın (123/ 741), Yahyâ el-Yezîdî (202/817) ve Şenbûzîyye (388/998) isnat edilen kıraatleri de muteber saymaktadır. ${ }^{193} \mathrm{O}$ halde yukarıda zikrettiğimiz üç şarta uyan okuyuş şekillerini, en azından ilâhî mesajın anlamlandırılmasına ve bununla ilgili bilimsel incelemelere derinlik kazandırması açısından Kur'ân kabul etmek daha doğru olacaktır.

İslâm alimleri, Osman Mushafi'nın bu yazım (resm, hat) özelliklerinin tevkîfî olup olmadığını ciddi biçimde tartışmışlardır. Ulemanın çoğunluğuna göre, İmâm Mushaf'in resmi tevkîfîdir; dolayısıyla, Kur'ân'ı yazarken ona muhalefet etmek caiz değildir. Çünkü Hz. Peygamber kâtiplerine vahyi böyle yazdırmış, Hz. Ebû Bekir Kur'ân'ı yazdırırken bu yazım şeklini esas almış, Hz. Osman da onun yolunu izlemiştir. Daha sonra tâbiîn ve müçtehit imamlar döneminde de bunun üzerinde ümmetin icmâ1 hasıl olmuştur. ${ }^{194}$ Zer-

\footnotetext{
189 ez-Zerkeşî, el-Burhân, I, 318.

190 Muhammed b. Muhammed el-Gazâlî, el-Müstasfâ, thk. M. Abdüsselam Abdü'ş-Şâfî, Beyrut: Dâru'lkütübi'l-ilmiyye, 1413, s. 81. Ayrıca bkz. ez-Zerkânî, Menâhilü'l-irfân, I, 302.

191 ez-Zerkânî, Menâhilü'l-irfân, I, 328.

192 ez-Zerkânî, Menâhilü'l-irfân, I, 329.

193 ez-Zerkânî, Menâhilü'l-irfân, I, 325.

194 ez-Zerkeşî, el-Burhân, I, 377; ez-Zerkânî, Menâhilü’l-irfân, I, 265.
} 
keşî, İmâm Mushaf'in hattının tevkîfî olduğunu ileri sürenlerin, 'O [Allah], kalemle [yazmayl] öğreten, insana bilmediğini belletendir.' [Alak (96), 4-5] ve 'Nûn. Kaleme ve yazdıklarına yemin olsun.' [Kalem / Nûn (68), 1] ayetlerini kendi görüşlerini doğrulayan birer delil olarak değerlendiklerini, belirtmekte, kendisi de onların bu yorumlarını onaylamaktadır. Üstelik Arapça harflerin isimlerinin Allah'nn Âdem Peygamber'e öğrettiği isimlerden olduğunu iddia ederek, görüşünü güçlendirmeye çalışmaktadır. ${ }^{195}$ Halbuki, bu ayetlerde ne Osman Mushafi kastedilmekte, ne de onun resminin tevkîfî olduğunu gösteren en ufak bir işaret bulunmaktadır.

Zerkeşı̂nin ilerleyen açıklamalarından, kadim ulemanın İmâm Mushaf'ın yazı stilinin (şeklü'l-Mushaf) tevkîfî olduğu hususunda son derece israrcı davrandıkları anlaşılmaktadır. Sözgelimi, Mâlik b. Enes'in (179/795) "Mushaf insanların öğrendikleri [bu devre ait] yazım usulleriyle yazılabilir mi?" sorusuna verdiği cevap, "Hayır; ilk yazıldığı gibi yazılmalıdır. Ümmetin alimlerinden hiç kimse buna muhalif değildir." şeklindedir. Yine Mâlik, ülü’lelbâb tamlamasında olduğu gibi, yazılan fakat telaffuz edilmeyen vâv ve elif harflerini Mushafta olduğundan farklı yazmanın caiz olup olmadığı yönündeki bir soruya, "Hayır" cevabı verdiği görülmektedir. Ahmed b. Hanbel (241/ 855) ise, bu görüşü bir adım daha ileri götürerek, "yâ, vâv, elif vb. harflerin yazımı hususunda Osman Mushafi'na muhalefet etmek haramdır." demektedir. ${ }^{196}$ Beyhakî (458/1066) de, Mushafın ilk yazım biçimine mutlaka uyulması gerektiğini savunmakta, bunu, sahabilerin sonrakilerden daha alim, daha temiz kalpli, daha doğru sözlü ve çok daha güvenilir olmalarına bağlamaktadır. ${ }^{197} \mathrm{Ne}$ var ki, ilâhî hitâbın yazım şeklinin tevkîfî olduğu görüşü, bazı kelimelerin yazımında belli bir standardın uygulanmamasından kaynaklanan önemli bir problemle karşı karşıyadır. Ebu'l-Abbâs el-Merâkeşî (721/1321), kelimelerde görülen bu yazım farklılıklarının, onların anlamlarında meydana gelen farklılıklardan kaynaklandığını, daha açık bir ifadeyle, onların değişik yerlerde değişik anlamlarda kullanılmalarının veya anlamlarına özel vurgu yapma gereğinin yazımlarında da farklılığa yol açtığını ileri sürerek, bu problemin üstesinden gelmeye çalışmaktadır. ${ }^{198}$ Sözgelimi, Neml Suresi'nin 21'inci ayetinde leüazzibennehû (onu cezalandıra-

\footnotetext{
195 ez-Zerkeşî, el-Burhân, I, 377-78.

196 ez-Zerkeşî, el-Burhân, I, 379; es-Suyûtî, el-i̇tkân, IV, 443; ez-Zerkânî, Menâhilü’l-irfân, I, 266-67; el-Hamed, Resmü'l-Mushaf, 197-99.

${ }^{197}$ Ebû Bekir Ahmed b. El-Hüseyin el-Beyhakî, Şuabu'l-îmân, thk. M. es-Saîd Busyûnî Zağlûl, Beyrut: Dâru'l-kütübi'l-ilmiyye, 1410, II, 548. Ayrıca bkz. ez-Zerkeşî, el-Burhân, I, 379; es-Suyûtî, el-ìtkân, IV, 443.

198 ez-Zerkeşî, el-Burhân, I, 380; el-Hamed, Resmü'l-Mushaf, 223 vd.
} 
cağım) ifadesi tek elif ile yazılırken, aynı ayetin devamında yer alan le(e)ezbehannehû (onu boğazlayacağım) ifadesi, boğazlama cezalandırmadan daha şiddetli bir anlam içerdiği için çift elif ile yazılmıştır. Bu imlâ şeklindeki ikinci elif harfi -ki, biz onu parantez içerisinde gösterdik- fazladan olup, yazıldığı halde okunmaz. Kur'an'da bunun daha başka örnekleri de vardır. Benzer biçimde, seü(ü)rîküm (size göstereceğim) ${ }^{199}$ ifadesinde olduğu gibi, bazı kelimelerde vâv ve yâ harflerinin de fazladan yazılıp, okunmadığı görülmektedir. Bazen de tam tersi bir imlâ ile, hem bu üç harf, hem de kelimenin asıl harflerinden üçüncüsü olan nûn harfi, ilgili kelimelerin bir kısmında yazıldığı halde, Rahmân ve lem tekü ${ }^{200}$ örneklerinde olduğu gibi, diğerlerinde yazılmamıştır, yani hazfedilmiştir. Asıl harfleri içerisinde uzatan harflerden birisi bulunan bazı kelimeler, bir yerde aslına uygun olarak yazılırken, başka bir yerde farklı bir uzatma harfi ile yazılmışı̧r. Nitekim salât (namaz) kelimesi, bazı ayetlerde elif harfi ile yazılırken, ${ }^{201}$ kalın okunmasını (et-tefhîm) sağlamak amacıyla genellikle vâv harfi ile yazılmıştır. Yine mecrâhâ kelimesinde ilk uzatma harfinin yâ harfi ile yazılması örneğindeki gibi, elif harfi ile yazılması gereken bazı kelimeler ince okunacak şekilde yâ harfi ile yazılmıştır. Bunlara ilaveten, kapalı tâ harfi ile yazılması gereken kelimelerden bir kısmı bazı ayetlerde açık tâ harfi ile yazılmıştır ki, şeceratün (bir ağaç), ni'metün, rahmetün kelimeleri buna örnek teşkil etmektedir. Ayrıca inne-mâ, eyne-mâ, külle-mâ örneklerinde olduğu gibi, peş peşe gelen iki edat, ayetlerin bir kısmında bitişik yazılırken, diğerlerinde ayrı yazılmıştır. Yaygın bir örnek olarak, bestah ve türevlerinin yazılışında olduğu gibi, bazı kelimelerle türevleri ayetlerin bir kısmında sîn, diğer kısmında da sâd harfi ile yazılmıştır. Usulcüler, birtakım deliller ve gerekçeler ileri sürerek, yazılıştaki bu farklılıkların doğru olduğunu savunmuşlar, onlardan çeşitli anlamlar çıkarmaya çalışmışlardır. ${ }^{202}$

Oysa bu imlâ farklılıkları, Ferrâ (207/822) ile İbn Kuteybe'nin (276/ 889) yaptı̆̆ı gibi, hem Mushaf'1 cem edip yazmakla görevli heyetteki kişilerin hatalarıyla, hem de Arap yazısının gelişim süreciyle ilişkilendirilebilir. ${ }^{203}$

\footnotetext{
199 A'râf (7), 145; Enbiyâ (21), 37.

${ }^{200}$ Gâfir / Mü'min (40), 50.

${ }^{201}$ Meselâ bkz. Enfâl (8), 35; En'âm (6), 162.

202 Ayrıntılar ve örnekler için bkz. Mukaddimetü Kitâbi'l-mebânî, 104-16, 137 vd.; İbnü'l-Cevzî, Acâibü ulûmi'l-Kur'ân, 111 vd.; ez-Zerkeşî, el-Burhân, I, 381 vd.; es-Suyûtî, el-İtkân, IV, 444 vd.; el-Hamed, Resmü'l-Mushaf, 223 vd.

Kur'ân'daki imlâ farklılıklarını gösteren gayet ayrıntılı bir liste için bkz. Hamidullah, Kur'ân-ı Kerîm Tarihi, 51 vd.

203 el-Hamed, Resmü'l-Mushaf, 206-08.
} 
Zaten yukarıdaki beyanlarından sonra Zerkeşî, Mushafın imlâ şeklindeki tevkîfîliğin İslâm'ın ilk asırlarına ait bir durum olduğunu, yazı tekniği ile ilgili bilgilerin canlı bir bitki gibi geliştiğini, insanların bu tekniklerin eskisini değil, yenisini öğrendiğini, bundan ötürü Kur'ân'ı ilk yazıldığı şekilde yazmanın bundan böyle karıșıklığa yol açacağını belirtmektedir. Bu görüşünü dile getirirken de, Mushaf' 1 ilk yazıldı $\breve{g} 1$ şeklinin muhafaza edilmesi gerektiğini özellikle vurgulamakla birlikte, bu yazıyı bilmeyenlerin Kur'ân'ı bozabilecekleri endişesiyle, onu ilk yazı biçimiyle yazmanın artık caiz olmadığını söyleyen İzzeddin b. Abdisselâm'a (660/1262) dayanmaktadır. ${ }^{204}$ Sadece yazının gelişmişlik derecesi değil, aynı zamanda vahiy dönemi Arapça'sının Hicâz bölgesinde konuşulan lehçesi, özellikle Kureyş lehçesi de Mushaf'ta uyulan imlâ usullerini etkilemiş olabilir. Bu cümleden olarak, halk bir kelimeyi çeşitli terkipler içerisinde nasıl söylüyorsa (kimi terkiplerde kalın, kimilerinde ince), o kelimenin bu telaffuza uygun olarak yazılması uygun görülmüş olabilir. Ancak kalın telaffuzun baskın olduğu Kureyş lehçesine göre gerçekleştirilen yazımda göz zevkinin de atlanmadığı, bu yüzden salâtî (namazım, duam) örneğinde olduğu gibi, eksiz olarak vâv harfi ile yazılan kalın okunuşlu bazı kelimelerin ek aldıklarında elif ile yazıldığı düşünülebilir. Bu yazım farklılıklarından bir kısmı, Mushaf'ı toplama işiyle görevlendirilen heyetteki kişilerin, gerek kendi aralarında, gerek yetkililerle, gerekse ilmî yetkinliğe sahip diğer sahabilerle yaptıkları istişarelere dayanarak tercih ettikleri tasarruflar olarak bile değerlendirilebilir. Nitekim, sadece İmam Mushaf'ın birtakım kelimelerinde değil, Ebû Bekir Mushafı ile Osman Mushafı (resmî Mushaf), hatta Hz. Osman'ın yazdırıp, İslâm aleminin çeşitli bölgelerine gönderdiği Mushaflar arasında -anlamı ciddi olarak etkilemeyecek düzeyde olmasa bile- azımsanmayacak sayıda birtakım farkların bulunduğu bir gerçektir. ${ }^{205}$

Görüşümüzü dayandırdığımız bu ihtimallerden biri veya hepsi doğru olsun ya da başka bir ihtimal söz konusu olsun, Mushaf ta bazı kelimelerin Arapça imlâ kurallarına uymayacak biçimde yazılmasının tevkîfî olamayacağı, bu farklı yazımlara -bazen ilgili kelimenin köküne işaret etme dışındaherhangi bir anlam ve fazilet yüklenemeyeceği açıktır. Bazı İslâm alimleri, ilâhî dinin ilk asırlarında oluşan, usulcüler tarafından genel olarak benimsenen, bizim de yukarıda atıfta bulunduğumuz klasik görüşe karşı çıkmışlardır. Bu bağlamda İbn Haldûn'un (808/1406) görüşlerini zikretmek isti-

\footnotetext{
204 ez-Zerkeşî, el-Burhân, I, 379.

205 Örnekler için bkz. Mukaddimetü Kitâbi'l-mebânî, 117-21; Ünal, Kur'ân'ın Anlaşılmasında Kıraat Farklılıklarının Rolü, 105-08.
} 
yoruz. Bu konuyu, eserinin "yazı sanatının insanlara mahsus sanatlardan biri olduğunu" işlediği bölümünde ele alan İbn Haldûn, çeşitli Arap kabilelerinde yazının gelişim tarihini zikrettikten sonra, Mushaf'ın imlâsını Hicâz bölgesinde kullanılan Arap yazısının gelişim süreci ile ilişkilendirmekte, bu yazının (özellikle Hicâz bölgesinde kullanılan yazının) İslâm'ın ilk yıllarında orta derecede sayılabilecek kadar bile güzelliğe sahip olmadığını, bunun da sahabiler tarafından yazıya geçirilen Mushafların yazımına yansıdığını, böylece yazı uzmanlarının tespit ettiği birçok kuralla bağdaşmayan bazı yazım hatalarının (kusur) ortaya çıktığını, fakat tâbiîlerin yeniden istinsah ettikleri Kur'ân'larda Tanrı'nın en hayırlı kulları tarafından yapılan bu hataları kutsayarak koruduklarını, bu kutsanmış hataların sonraki Müslümanlar tarafından da hiç değiştirilmeden sürdürüldüğünü belirtmektedir. Sonra da, sahabilerin mükemmel ve kusursuz yazı yazabildiklerini ileri sürerek, Mushaf ta kurallara aykırı görünen bazı yazım şekillerini birtakım sebeplere bağlayan ve çeşitli anlamlar yükleyerek bunları tevil eden kişileri "gafiller" olarak nitelendirmekte, onların bu düşüncelerinin temelsiz kuru bir iddiadan ibaret olduğunu ileri sürmektedir. ${ }^{206}$

\section{N. Sonuç ve Değerlendirme}

Sonuç olarak, klasik anlayışta Kur'ân, yukarıda özetlemeye çalıştığımız temel ve şekilsel özellikleriyle Allah'ın kelâmıdır. O, hem manasıyla, hem de metniyle ilâhî bir kitaptır; Allah'ın mesajı nüzulünden günümüze kadar orijinalliğini korumuştur. ${ }^{207} \mathrm{~Hz}$. Osman'ın oluşturduğu ilmî heyet tarafından cem edilen Mushaf ta bazı kelimelerin dil kaidelerine aykırı olarak yazılması ve İslâm ülkesinin değişik merkezlerine gönderilen nüshalar arasında bazı farklar bulunması bile bu gerçeği değiştirmemektedir. Çünkü bunlar büyük ölçüde önemsiz boyutta olup, ilâhî mesajın bozulması gibi bir sonuç doğurmamaktadır. Usulcülerin genel kanaatlerine göre, Kur'ân ayetlerinin tertibi tevkîfî olup, bunların sıralarını değiştirmeye kimsenin hakkı yoktur; surelerinin sıralaması ise, tevkîfî olmayıp, sahabilerin içtihatlarına dayanmaktadır. Ancak verilerin detaylı incelemesi, "ayetlerin tamamına yakınının tevkîfen, gerçekten çok az bir kısmının içtihâden sıralandığını; buna karşılık, surelerin önemli bir kısmının tevkîfen, azımsanmayacak bir kısmının da içtihâden tertip edildiğini" söylemenin daha gerçekçi olduğunu göstermektedir. Gelenek içerisinde böyle eğilimler de ortaya çıkmıştır. Bu görüşlerden

\footnotetext{
206 İbn Haldun, Mukaddime, çev. Zakir Kadiri Ugan, İstanbul: MEB, 1986, II, 409-14.

${ }^{207}$ Mukaddimetü Kitâbi'l-mebânî, 103.
} 
hangisi tercih edilirse edilsin, kesin olan şudur ki, bunlar ayetlerin sahihliklerine ilişkin tartışmalar olmayıp, elimizdeki tertibiyle Kur'ân, asırlar boyunca bütün Müslümanlar tarafından genel kabul görmüștür. Bu araştırmada zikrettiğimiz görüşler doğrultusunda Kur'ân, "Peygamber'e (SAV) indirilen, Mushaflarda yazılı bulunan, tevatürle nakledilen ve okunușuyla (tilâvet) ibadet edilen mu'ciz kelamdır." şeklinde tanımlanabilir. Kur'ân'ı bu șekilde tanımlamak, usulcüler, fakihler ve Arapça bilginleri arasında ittifak edilen bir husustur. ${ }^{208} \mathrm{Bu}$ Kur'ân tasavvuru, hangi mezhepten olursa olsun, hangi farklı görüşleri benimserse benimsesin, bütün Müslümanların ortak tasavvurudur. Tarih şahittir ki, hiçbir İslâm mezhebinin farklı bir Kur'ân'ı olmamıştır. Bu bakımdan, bazı çevrelerin Hindistan'ın Bankipore Kütüphanesi'nde bulunan, nûreyn ve velâye isimlerini taşıyan iki uydurma / apokrif sure ihtiva eden bir nüshayı Şîa'ya mal ederek, alternatif Kur'ân oluşturma çabaları, hem ilmi ve tarihi gerçeklerle bağdaşmaması, hem de iyi niyetten uzak olması nedeniyle sırf bir hayal olarak kalmaya mahkumdur. ${ }^{209}$

Her çağdaki ve her yerdeki Müslümanların hemen hemen tamamı tarafından kabul edilerek, vazgeçilmez bir gelenek haline dönüştürülmüş olan bu Kur'ân anlayışı, hem ayetlere bakış açısını, hem onların yorumlarını, hem de bu esnada uyulan ve uygulanan metotları (usûl) derinden etkilemiştir. Temel ve şekilsel özellikleri itibariyle -bazı özelliklerinin içtihâda dayanması hariç- ilâhî oluşu, gayet tabiî ki, Kur'ân'ın metninin (nass) son derece önemsenmesi, çoğaltılması ve yorumlanması esnasında diğer bütün öğelerden önce bu metnin esas alınması sonucunu doğurmuştur. Bu yüzden klasik anlayışta esas olan, görünen / zahir anlamdır ve herhangi bir haklı nedene dayanmadıkça, onunla bağdaşmayan hiçbir Kur'ân yorumu muteber değildir. ${ }^{210}$ Ancak bu, ayetlerin sırf literal anlamlarına takılıp kalmayı değil, ilâhî kitabın metni üzerindeki hassasiyeti ifade etmektedir. Zira İslâm tarihi boyunca, zaman zaman metne aşırı bağlı kalan yorumlar ortaya çıkmış olsa bile, gerek murâd-ı ilâhîyi tespit etme çabası, gerek yorum esnasında ayetlerin anlamlarını etkileyen tarihi arka-planlarının, amaçlarının, metinsel bağlamlarının (siyâk) vs. göz önünde tutulması, gerekse bir ayetin ilgili diğer ayetlerin, şiirlerin, hadislerin vs. yardımıyla tefsir edilmesi, sırf literal anla-

208 ez-Zerkânî, Menâhilü'l-irfân, I, 20; Subhî es-Sâlih, Mebâhis fî ulûmi'l-Kur'ân, 21 (Türkçe'si için bkz. Kur'ân İlimleri, 18); Cerrahoğlu, Tefsir Usulü, 33-34; Zarzûr, Ulûmu'l-Kur'ân, 46.

209 Bu konuda geniș değerlendirmeler için bkz. Cerrahoğlu, Tefsir Usulü, 77-78; Sadık Kılıç, Tarihsellik ve Akılcılık Bağlamında Kur'ân'ı Anlama Sorunu, İstanbul: İhtar Yayıncılık, 1999, s. 189205.

210 Geniş bilgi için bkz. ez-Zerkeşî, el-Burhân, II, 146 vd. 
mın belirleyici olmasını engellemektedir. Klasik Kur'ân tasavvurunun tefsir ve usul üzerindeki asıl etkisi ise, ilâhî kelâmın üslubu ile ilgili değerlendirmelerde kendini göstermektedir. Zira Kur'ân'ın rengârenk üslubu, onu, Arap dili ve edebiyatı ile olduğu kadar, ahlâk, tarih, hukuk, iktisat, psikoloji, evrenbilim gibi beşeri bilimlerle de yüz yüze getirmekte, bu bilimlerle ilgili olan ayetlerin daha iyi anlaşılabilmesi için onlardan yararlanmayı adeta zorunlu kilmaktadır. Yine bu üslup, ilâhî hitapta geçen kelime ve kavramların âmm-hâs, mutlak-mukayyed, hakikat-mecâz, garîb, müşterek vs. olup olmadıklarının tespit edilmesini, tedrîcen konan hükümlerin, nâsih, mensuh, müşkil veya mücmel olan ayetlerin, nüzul sebeplerinin, ayet sonlarındaki musiki âhenginin, lafız-mana bütünlüğünün, ayetler arasındaki münasebetlerin incelenmesini gerektirmektedir. Tefsir usulünün temel alanına işaret eden bu konularla ilgili olarak müfessirin oluşturduğu bakış açısı, onun ayetlere getireceği yorumları doğrudan etkilemekte, daha açı bir anlatımla, Kur'ân'ı o, oluşturduğu bu bakış açısı doğrultusunda tefsir etmektedir. 
AüifD 47 (2006), sayı l, s. 55-66

\title{
Hukukun İşlevleri Arasındaki Zıtlık ve Adaletin Üstü̈nlüğ̈ii Bakımından İslâm Hukuku
}

\author{
ADNAN KOSUM \\ DOÇ.DR., SÜLEYMAN DEMIREL Ü. İLAHIYAT FAKÜLTESI \\ e-mail: akosum@ilahiyat.sdu.edu.tr \\ abstract
}

The Islamic Law from View Point of Contradiction between the Functions of Law, and the Superiority of Justice. The law plays active role in social life. To understand its nature and to put it into practise successfully depends on the knowledge of its functions and the knowledge of the relations between these functions. The functions of law can be enumerated as to realize justice, to meet social needs and to order social life. These functions, even within single legal system, sometimes contradict each other. Thus, those who practise the law must fallow a balanced and harmonic approach in application of these functions to reach ultimate goal of the realization of justice.

Key words

Justice, social order, practical aim.

\section{Giriş}

Hukuk, fertlerin ve toplumun hayatında aktif ve aktüel bir rol oynar. Zira o, adalete hizmet eden beşeri bir hayat düzenidir. Bu nedenle tarih boyunca bütün toplumlarda hukuk bir şekilde var olagelmiştir. Hukukun işlevlerinin ve işlevler arasındaki münasebetin tam olarak bilinmesi ve değerlendirilmesi, onun mahiyetini anlama için olduğu kadar, başarılı bir hukuk uygulaması için de önem taşımaktadır.

Hukukçular tarafından hukukun değişik işlevleri olduğu ortaya konmuştur. Bu işlevlerin sayısı kimi yazarlar tarafından çoğaltılmakla birlikte bunların adaleti gerçekleştirme, düzen kurma ve sosyal ihtiyaçları karşılama gibi başlıklar altında toplanabileceği söylenebilir. ${ }^{1}$ Bu nedenledir ki hukuk,

1 Güriz, Adnan, Hukuk Başlangıcl, Ankara 1992, s. 2. 